\title{
Effectiveness of the thermal mass of external walls on residential buildings for part-time part-space heating and cooling using the state-space method
}

Article

Accepted Version

Creative Commons: Attribution-Noncommercial-No Derivative Works 4.0

Deng, J., Yao, R., Yu, W., Zhang, Q. and Li, B. (2019) Effectiveness of the thermal mass of external walls on residential buildings for part-time part-space heating and cooling using the state-space method. Energy and Buildings, 190. pp. 155-171. ISSN 0378-7788 doi:

https://doi.org/10.1016/j.enbuild.2019.02.029 Available at https://centaur.reading.ac.uk/82376/

It is advisable to refer to the publisher's version if you intend to cite from the work. See Guidance on citing.

To link to this article DOI: http://dx.doi.org/10.1016/j.enbuild.2019.02.029

Publisher: Elsevier

All outputs in CentAUR are protected by Intellectual Property Rights law, including copyright law. Copyright and IPR is retained by the creators or other copyright holders. Terms and conditions for use of this material are defined in the End User Agreement. 


\section{www.reading.ac.uk/centaur}

\section{CentAUR}

Central Archive at the University of Reading

Reading's research outputs online 
Manuscript for Energy and Buildings

\section{Effectiveness of the thermal mass of external walls on residential buildings for part-time part-space heating and cooling using the state- space method}

Jie Deng ${ }^{1, *}$, Runming $\mathrm{Yao}^{1}$, Wei $\mathrm{Yu}^{2, * *}$, Qiulei Zhang ${ }^{3}$, Baizhan $\mathrm{Li}^{2,3}$

${ }^{1}$ School of the Built Environment, University of Reading, Reading RG6 6DF, UK

${ }^{2}$ Joint International Research Laboratory of Green Buildings and Built Environments (Ministry of Education), Chongqing University, Chongqing 400045, China

${ }^{3}$ National Centre for International Research of Low-carbon and Green Buildings (Ministry of Science and Technology), Chongqing University, Chongqing 400045, China

Corresponding authors:

* School of the Built Environment, University of Reading, Chancellors Building, Shenfield Road, Reading, RG6 6DF, UK E-mail: j.deng@ reading.ac.uk, deng-jie2@163.com (J. Deng)

** Chongqing University, Campus B, Chongqing 400045, China

E-mail: yuweixscq@126.com (Wei Yu) 


\section{Abstract}

A high-resolution time interval numerical model is more accurate to analyze the building dynamic thermophysical processes in the intermittent occupancy, while relevant professional software, such as EnergyPlus, is not compatible with different time intervals. The present study aims to investigate the thermal mass effectiveness of external walls on the part-time part-space operation of heating and cooling of a typical residence. A high-resolution model of a typical 3-occupant residential apartment has been developed using the state-space method and validated by the simulation results from EnergyPlus. The model is then amended to calculate building energy demands with fixed heat and cold supply powers from the perspective of system control, in order to interpret the effectiveness of thermal mass with identical recommended $U$-value in the HSCW (Hot Summer and Cold Winter) zone in terms of room operative temperatures. It is found that high thermal mass does not help to reduce ideal building loads in the residential buildings in the HSCW zone, but it will improve indoor thermal comfort control in real engineering compared to low thermal mass. Regarding thermal insulation placements of heavy weight external walls under the same thermal mass, it is evidenced that the adoption of internal insulation weakens the thermal mass impact of the heavy weight wall composition compared to that of external insulation. It is inferred that the high thermal mass in the composition of external walls should be exposed to the indoor air to avoid overheating in the cooling conditions.

Keywords: Intermittent occupancy; Hot Summer and Cold Winter (HSCW) zone; Thermal mass of external walls; Wall thermal insulation; Room operative temperature 


\section{List of symbols}

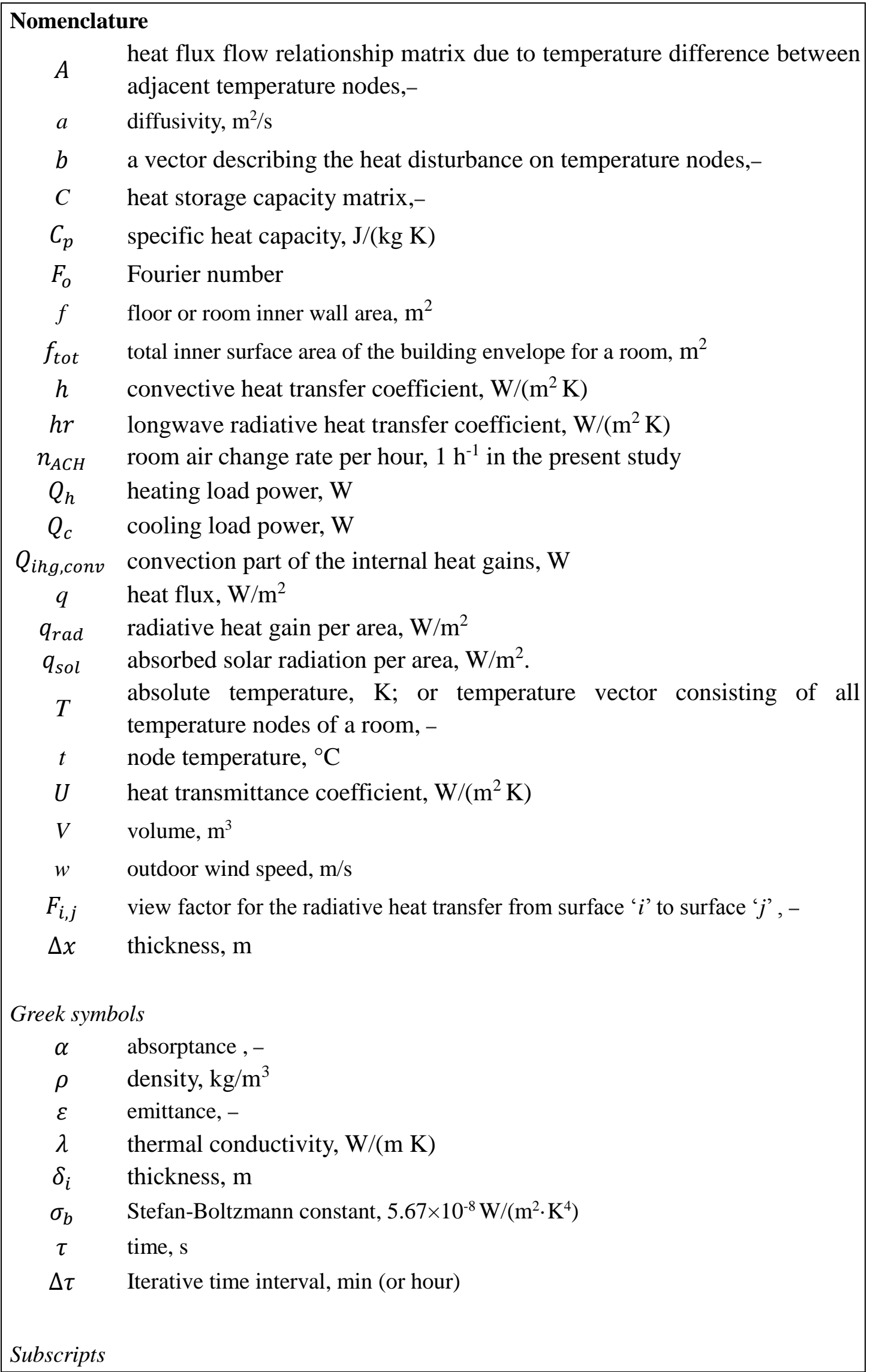




\begin{tabular}{|cl|}
\hline air & indoor air \\
a,out & outdoor air \\
$c$ & cooling \\
conv & convective heat transfer \\
$h$ & heating \\
$i$ & $i$-th node \\
$i-1$ & $(i-1)$-th node \\
$i+1$ & $(i+1)$-th node \\
$j$ & room inner wall surface $\mathrm{j}$ \\
in,wall & inner wall surface \\
rad & radiative heat transfer \\
sky & sky background environment \\
$w 1$ & inner node of double glazing \\
$w 2$ & outer node of double glazing \\
target & room target control parameter \\
$n+1$ & outer surface \\
$n+1$, air & air close to the outer surface ' $\mathrm{n}+1$ ' \\
$n+1, j$ & wall inner surface ' $\mathrm{j}$ ' of the room related to outer surface ' $\mathrm{n}+1$ ' \\
1 & inner surface \\
1, air & air close to the inner surface ' 1 ' \\
$1, j$ & wall inner surface ' $\mathrm{j}$ ' of the room related to inner surface ' 1 '
\end{tabular}




\section{Introduction}

It is widely accepted that occupancy is one of the most important factors impacting building energy consumptions [1-3]. In an intermittent occupancy of residential buildings, energy demands of space H\&C (Heating and Cooling) are different from those in a continuous occupancy in terms of thermal comfort demands. A typical representative of intermittent occupancy is the part-time part-space usages of residential buildings in the HSCW (Hot Summer and Cold Winter) zone of China. In the HSCW zone, the climate in winter is not as cold as in northern China and space cooling in summer commonly dominates building thermal energy consumptions. Part-time partspace $H \& C$ is widely accepted by people in the region [4-6]. In the intermittent occupancy, the concept of heat storage and release through the thermal mass of building envelope plays a role in the building energy demands [7]. Although it is widely accepted that high thermal mass will be an advantage of building energy conservation in hot climates, they tend to be not so effective in cold climates [7]. To ascertain the effectiveness of external wall thermal mass on residential buildings in the part-time part-space pattern, it is supposed that a high-resolution building model will be more precise to characterize the dynamic thermophysical processes of residential buildings. However, relevant professional software, such as EnergyPlus [8], is not compatible with different iterative time intervals and a 1-h time interval is commonly adopted in building simulations. In this sense, it is necessary to develop high-resolution building simulation models for investigating the thermal mass effect of building envelopes on building energy demands in the intermittent occupancy. 
Essentially, the thermal mass effect is neglected in a simple estimation of heat transfer through building envelopes in terms of heat transmission coefficient ( $U$-value), as the simple estimation is based on the steady-state condition [9]. The nominal $U$-value is calculated in Equation (1) [10]. Ferrari and Zanotto [9] reviewed the approaches or indices being developed to approximate the dynamic behavior of buildings in the steady-state analysis and declared that the application of simplified parameters approximating the dynamic behavior in the single-element analysis would give inconsistent results. Byrne et al. [11] investigated the in situ thermal behavior of a case study building and its components under transient and quasi-steady environmental conditions and concluded that predicted values of heat loss using assumed standardized material properties of the existing structure overestimated the impact of the retrofitted insulation on heat loss through the ceilings and walls. Reilly and Kinnane [7] verified the overestimation of retrofitted insulation effect was due to the thermal mass of building envelope in dynamic behavior. Besides, a metric for characterizing the effectiveness of thermal mass elements in buildings had been proposed by Taylor and Miner [12], providing guidance on the most significant contributors to indoor thermal mass.

$$
U=\frac{1}{\left(1 / h_{\text {inner }}\right)+\sum \delta_{i} / \lambda_{i}+\left(1 / h_{\text {external }}\right)}
$$

where $\delta_{i}(\mathrm{~m})$ and $\lambda_{i}(\mathrm{~W} /(\mathrm{m} \mathrm{K}))$ are the thickness and the thermal conductivity of each layer of a wall. $h_{\text {inner }}$ and $h_{\text {external }}\left(\mathrm{W} /\left(\mathrm{m}^{2} \mathrm{~K}\right)\right)$ are the internal and external 
comprehensive heat transfer coefficients, respectively.

With regard to the thermal mass impact on building energy consumptions, Reilly and Kinnane [7] disclosed that one cannot use any material property, nor even the total thermal mass of a building, to quantify a waste of heat or cold in an intermittent occupancy mode because the proportion of extra heat required depends on the order of layers in the wall as well as on details of the thermal load case. Thermally heavy buildings with a high thermal mass in the envelope are supposed to help lower the building energy consumption by decreasing cooling demands in a continuous energy use pattern in warm climates [13]. Siddiqui et al. [14] argued that the use of thermal mass incorporating PCMs (Phase Change Materials) into the building envelope was found to contribute to energy savings of $10-15 \%$ in the Toronto Net-Zero Energy House compared to the case of commonly available forms of thermal mass. Karlsson et al. [15] simulated the influence of thermal inertia in building structures with a conceptual model and their model tests done in a cold-climate case showed that the passive energy storage through high thermal mass could significantly change the power consumption pattern while the total energy consumption in most cases was not much influenced. Xu et al. [16] argued that energy saving rate for intermittent heating of office buildings can reach about $20 \%$ in a typical week compared to continuous heating and the required heating capacity for each room in an intermittent heating strategy was 1.1-1.3 times that of a traditional continuous heating system. When it comes to the part-time part-space $\mathrm{H} \& \mathrm{C}$ of residential buildings in the HSCZ zone, the thermal mass impact of external walls in 
the intermittent occupancy pattern should be rethought to confirm its effectiveness.

On the other hand, multi-layer material walls with thermal insulation are commonly used in contemporary building construction and the layer sequence and distribution affect the wall behavior by virtue of its overall thermal inertia, or heat storage capacity [17]. Gou et al. [18] used a composition of reinforced concrete and XPS board for walls of multi-story residential buildings to conduct multi-objective optimisation of passive solutions for achieving thermal comfort and minimising building energy demands in Shanghai. They concluded that a high thermal inertia index for the south wall and a low thermal inertia index for the north wall are helpful in improving the indoor thermal comfort and promoting the building energy performance. Thermal insulation of external walls in the HSCW zone is proven to be effective for energy savings [19, 20]. Studies on the optimum insulation thickness of building external walls are found in [2123]. Aditya et al. [24] gathered most recent developments on the building thermal insulations and discussed the life-cycle analysis. Most of the aforementioned studies on building thermal insulation are useful but the impact of thermal insulation placement within the external wall compositions should be clarified further, as even external walls with the same thermal mass (identical $U$-value) but different insulation orders within the wall would probably perform differently for building energy efficiency. Numerical simulation done by Meng et al. [25] showed that different wall insulation forms had a remarkable effect on the temperature response rate and the heat flow of the inner surface under intermittent air-conditioning operation, although they had the same heat 
transmittance coefficients. Al-Sanea et al. [26] pointed out that thermal mass should be placed on the inside, relative to the insulation layer, under steady periodic conditions. Although Pan et al. [7] conducted analysis on passive energy conservation approaches of residential buildings in Shanghai and reported that the thermal response rate of internal insulation was faster that of external insulation, they did not undertake a quantitative analysis to show to what extent the internal insulation of external walls performs better than external insulation for energy savings. Yuan et al. [27] investigated the effects of insulation placement and thermal resistance on heat transfer of walls in Shanghai climate and argued that the energy saving of rooms with inside insulation was at least $18 \%$ higher than that of rooms with outside insulation. However, strict model validation was not found in their work. Moreover, researches on wall thermal mass impact based on building components rather than the whole building, such as $[7,26]$, should be further verified with the whole building model. For assessing the actual impact of building envelope thermal inertia, studies on the scale of a whole building are more valuable than a simple component analysis [28].

In summary, high-resolution time interval models are more accurate to analyze the building dynamic thermophysical processes and thermal mass effect in the intermittent occupancy, while relevant professional software, such as EnergyPlus, use a time interval of 1 hour for simulations. The difference of thermal insulation placements of external wall compositions under the same thermal mass for building energy conservation needs to be further explored in part-time part-space $\mathrm{H} \& \mathrm{C}$ pattern. The 
present study aims to ascertain the impact of external wall thermal mass with different compositions and different thermal insulation placements under identical recommended $U$-value in the HSCW zone of China. A typical 3-occupant building apartment model is developed in Matlab and validated to testify the precision of high-resolution models with time intervals smaller than 1 hour. Besides, most of previous studies on the impact of thermal mass on building energy conservation were based on room air temperature instead of room operative temperature. Actually, the room operative temperature defined as the equal combination of indoor air and mean radiant temperature on room wall inner surfaces - should be used as the indicator for assessing room thermal comfort, because it represents the occupant perceived temperature $[29,30]$. The established model is then amended to calculate the building energy demands with fixed $\mathrm{H} \& \mathrm{C}$ supply powers from the perspective of system control, in order to illustrate the impact of thermal mass in terms of room operative temperature.

\section{The method}

The whole framework of the present study is illustrated in Figure 1. 


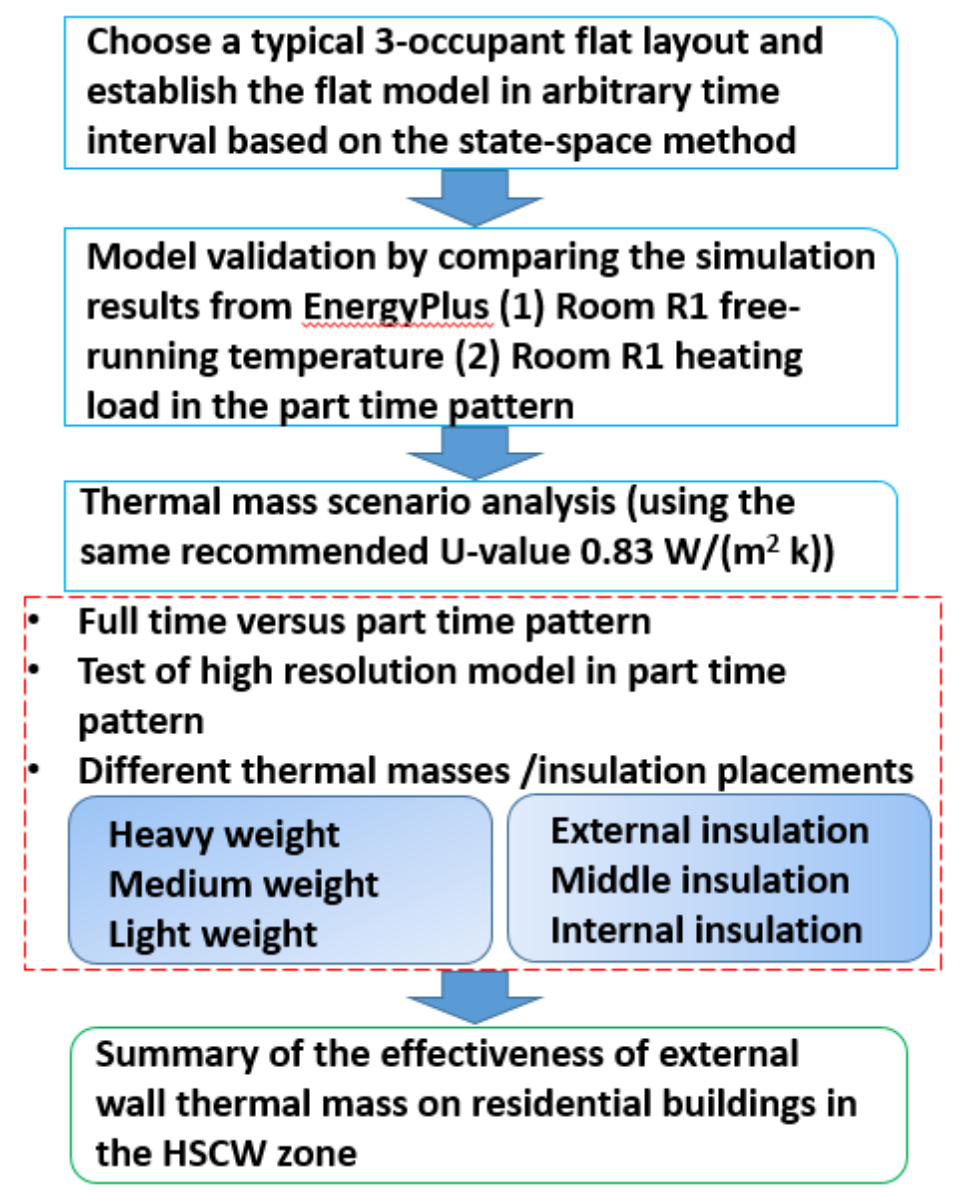

Figure 1 Research framework of the present study

\subsection{Physical model description}

In the present study, a typical 3-occupant building apartment layout identified from a variety of multi-story residential buildings in Chongqing city is chosen as the studied object. The typical 5-room flat layout is simplified in Figure 2 with a total floor area of $70.2 \mathrm{~m}^{2}$. Three functional rooms involving 2 bedrooms (R1, R3) and 1 sitting room (R5) are required for heating and cooling in relevant periods stipulated in the Design Standard 2010 [31] (heating: $1^{\text {st }}$ December to $28^{\text {th }}$ February; cooling: $15^{\text {th }}$ June to $31^{\text {st }}$ August). The window to wall ratio (WWR) on the south walls is chosen as 0.4 and 
WWRs on the other walls are 0.3 referring to the building code.

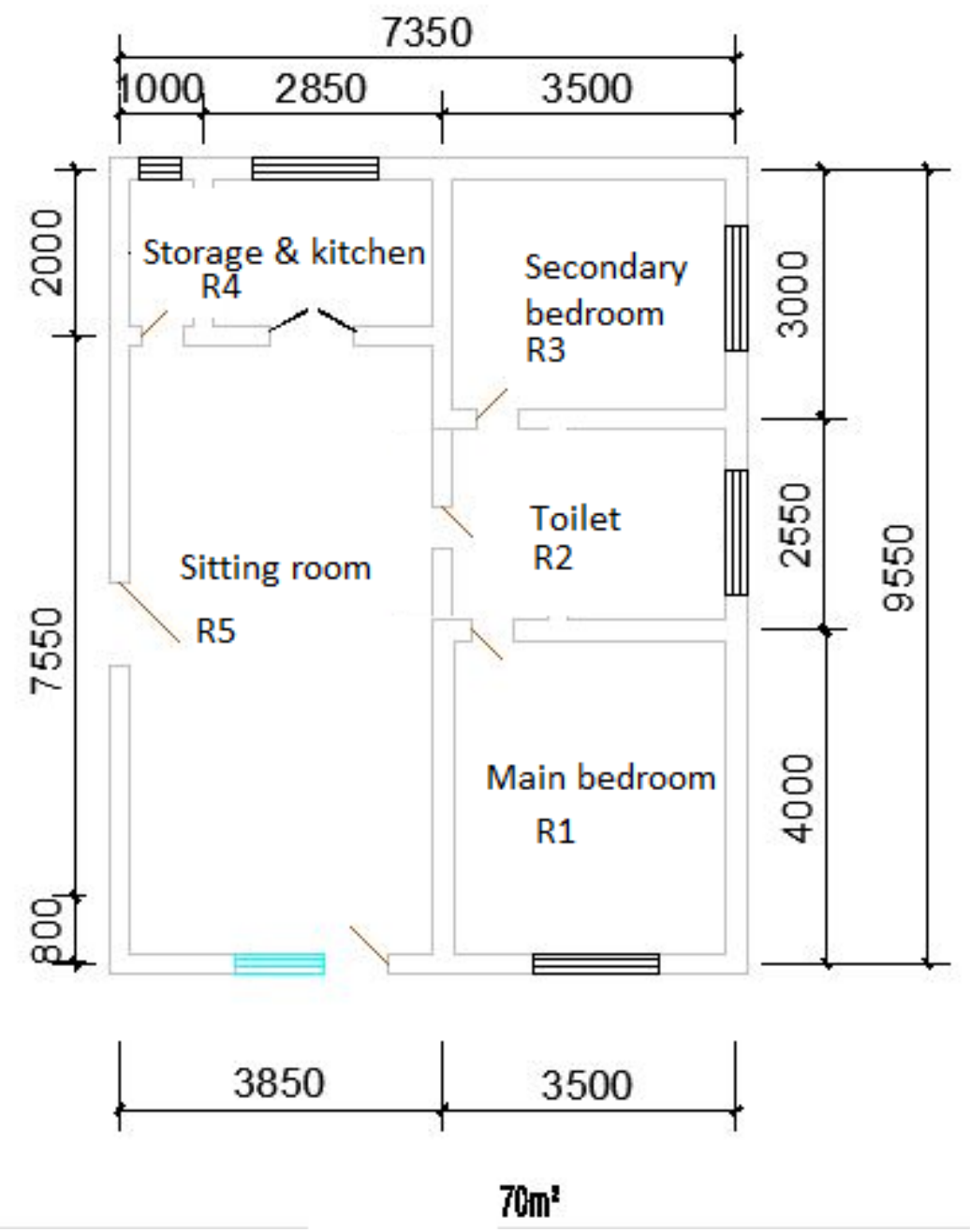

Figure 2 Plain layout of a typical 3-occupant building apartment

\subsubsection{Mathematical model based on the State-Space Method}

A dynamic thermophysical process model of the typical 5-room flat is established based on the state-space method $[32,33]$. Peripheral walls of the flat are assumed as external walls exposed to outdoor environment. The flat is assumed to be in a multi-story building and cyclic boundary conditions are supposed on the external surfaces of the ceiling and the floor. For the multilayer building envelope components (walls, ceiling, floor), it is assumed that the heat transfer is one-dimensional along the thickness and 
each layer can be discretized according to Fourier number $F_{o}=a \cdot \Delta \tau / \Delta x^{2}$ [34], where $a$ is the diffusivity of the building material and $\Delta \tau$ is the iterative time interval (conventionally $\Delta \tau=1 \mathrm{~h}$ ). In the present study, the spatial step $(\Delta x)$ of each layer is chosen as $\Delta x=\sqrt{a \cdot \Delta \tau}\left(F_{o}=1\right)$. According to the discretization principle, when the multilayer building envelope component is divided into $\mathrm{n}$ layers, ' $n+1$ ' temperature nodes are used to describe the thermal balance of the building component. Taking the first node ' 1 ' as the inner surface and ' $n+1$ ' as the outer surface, the temperature nodes from inner to outer are described in Equations (2-4) [34].

For the inner surface (node ' 1 '):

$$
\frac{1}{2} C_{p, 1} \rho_{1} \Delta x_{1} \frac{d t_{1}}{d \tau}=h_{1}\left(t_{1, a i r}-t_{1}\right)+\frac{\lambda_{1}}{\Delta x_{1}}\left(t_{2}-t_{1}\right)+\sum_{j} h r_{1, j}\left(t_{1, j}-t_{1}\right)+q_{r a d, 1}
$$

For the intermediate nodes (node ' $i$ '):

$$
\left(\frac{1}{2} C_{p, i-1} \rho_{i-1} \Delta x_{i-1}+\frac{1}{2} C_{p, i} \rho_{i} \Delta x_{i}\right) \frac{d t_{i}}{d \tau}=\frac{\lambda_{i-1}}{\Delta x_{i-1}}\left(t_{i-1}-t_{i}\right)+\frac{\lambda_{i}}{\Delta x_{i}}\left(t_{i+1}-t_{i}\right)
$$

For the outer surface (node ' $n+1$ '):

$$
\begin{aligned}
& \frac{1}{2} C_{p, n} \rho_{n} \Delta x_{n} \frac{d t_{n+1}}{d \tau}=h_{n+1}\left(t_{n+1, a i r}-t_{n+1}\right)+\frac{\lambda_{n}}{\Delta x_{n}}\left(t_{n}-t_{n+1}\right)+\sum_{j} h r_{n+1, j}\left(t_{n+1, j}-\right. \\
& \left.t_{n+1}\right)+q_{r a d, n+1}
\end{aligned}
$$

Double glazing window is adopted in the model due to recommended window $U$-value $\left(2.8 \mathrm{~W} /\left(\mathrm{m}^{2} \mathrm{~K}\right)\right)$ in the Design Standard 2010 [31]. Thus, two nodes 'w1' and 'w2' are considered for each window and the thermal balance equations are given in Equations (5) and (6).

$$
C_{p w 1} \rho_{w 1} \Delta x_{w 1} \frac{d t_{w 1}}{d \tau}=h_{c o n v, w 1}\left(t_{w 1, a i r}-t_{w 1}\right)+\sum_{j} h r_{j, w 1}\left(t_{w 1, j}-t_{w 1}\right)+q_{s o l, w 1}+
$$


$C_{p w 2} \rho_{w 2} \Delta x_{w 2} \frac{d t_{w 2}}{d \tau}=h_{c o n v, w 2}\left(t_{w 2, a i r}-t_{w 2}\right)+\sum_{j} h r_{j, w 2}\left(t_{w 2, j}-t_{w 2}\right)+q_{s o l, w 2}+$ $q_{\text {rad,w2 }}$

The indoor air of each room is assumed to be a lumped parameter temperature node and its thermal balance is given in equation (7).

$$
\begin{aligned}
& \quad C_{\text {p,air }} \rho_{\text {air }} V_{\text {air }} \frac{d t_{\text {air }}}{d \tau}=\sum_{j} h_{j} f_{j}\left(t_{j}-t_{\text {air }}\right)+C_{p, \text { air }} \rho_{\text {air }} \frac{n_{A C H} \cdot V_{\text {air }}}{3600}\left(t_{a, \text { out }}-t_{\text {air }}\right)+ \\
& q_{\text {conv }}+q_{\text {hvac }}
\end{aligned}
$$

The thermal balance equations involving all the temperature nodes for each room can be rewritten in a set of linear differential equations in the matrix form [34]:

$$
C \dot{T}=A T+b
$$

where $C$ represents the heat storage capacity matrix; $A$ denotes the heat flux flow relationship matrix due to temperature difference between adjacent temperature nodes; $b$ is a vector describing the heat disturbance on temperature nodes. $T$ is a temperature vector consisting of all the calculating temperature nodes for the room.

\subsubsection{Heat transfer coefficients}

The longwave radiative heat transfer coefficient between two different surfaces is calculated in Equation (9) for simplification [34].

$$
h r_{j}=\frac{f_{j}}{f_{t o t}} \varepsilon_{j} \sigma_{b}\left(T_{i}^{2}+T_{j}^{2}\right)\left(T_{i}+T_{j}\right)
$$

The convective heat transfer coefficients on the vertical surface of inner walls, on the 
floors and ceilings are $3.5,4.0,1.0 \mathrm{~W} /\left(\mathrm{m}^{2} \mathrm{~K}\right)$ respectively, referring to the DeST software $[35,36]$. The external comprehensive heat transfer coefficient is determined by equations (10) and (11) [37] instead of an identical value for different cities of China [38]. The sky background temperature is calculated by Equation (12) [39].

$$
\begin{aligned}
& h_{\text {conv,aout }}=2.8+3 \mathrm{w} \\
& h r_{\text {wall,aout }}=\sigma_{b}\left(T_{\text {air }}^{4}+T_{\text {sky }}^{4}\right) /\left(T_{\text {air }}-T_{\text {a,out }}\right) \\
& T_{\text {sky }}=0.0552 T_{a, \text { out }}^{1.5}
\end{aligned}
$$

\subsection{Calculating conditions and model parameter setting}

The typical meteorological year data developed in [40] for the three representative cities Chongqing, Changsha and Shanghai in the HSCW are used as the weather data inputs in different cases. The compositions of building envelope in the benchmark condition with heavy weight external walls are listed in Table 1 and the properties can be found in [38]. Emittance of the wall inner plastering surface is 0.94 and emittance of the glazing is 0.84 . The absorptance of the inner and outer surface of external walls is chosen as 0.7 referring to the default conditions in EnergyPlus [41]. An air change rate of $1.0 \mathrm{~h}^{-1}$ is chosen for all the five rooms according to the Design Standard 2010 [31]. Natural ventilation is not considered in the model. The occupancy schedule in the part time pattern is given in Table 2 (The timesheet might be slightly different for different residents, but the main conclusions of the study will not be changed). For the calculations of internal heat gains, lighting and equipment densities are $6,4.3 \mathrm{~W} / \mathrm{m}^{2}$, 
respectively and the fractions of convection and radiation related to relevant internal heat gains are referred to the default values in EnergyPlus [41]. Solar radiation model of internal heat gains is referred to relevant formulas in $[37,41]$. Occupant sensible and latent heat dissipation are 70,60 W/per, respectively. No internal heat gains are considered for Rooms R2 and R4.

Table 1 Building envelope components of the benchmark condition

\begin{tabular}{|c|c|c|}
\hline $\begin{array}{l}\text { Building component } \\
\text { type }\end{array}$ & Composition & $\begin{array}{l}U \text {-value } \\
\left(\mathrm{W} / \mathrm{m}^{2} \mathrm{~K}\right)\end{array}$ \\
\hline $\begin{array}{l}\text { External wall (from } \\
\text { inside to outside) }\end{array}$ & $\begin{array}{l}38.7 \mathrm{~mm} \text { EPS insulation }+15 \mathrm{~mm} \text { cement } \\
\text { mortar }+240 \mathrm{~mm} \text { reinforced } \\
\text { concrete }+15 \mathrm{~mm} \text { plasterboard }\end{array}$ & 0.83 \\
\hline Internal wall & $\begin{array}{l}15 \mathrm{~mm} \text { plasterboard }+120 \mathrm{~mm} \text { clay brick } \\
+15 \mathrm{~mm} \text { plasterboard }\end{array}$ & 2.56 \\
\hline $\begin{array}{l}\text { Ceiling (from inside } \\
\text { to outside) }\end{array}$ & $\begin{array}{l}20 \mathrm{~mm} \text { plasterboard }+150 \mathrm{~mm} \text { reinforced } \\
\text { concrete }+20 \mathrm{~mm} \text { cement mortar }\end{array}$ & 2.96 \\
\hline $\begin{array}{l}\text { Floor (from inside } \\
\text { to outside) }\end{array}$ & $\begin{array}{l}20 \mathrm{~mm} \text { cement mortar }+150 \mathrm{~mm} \\
\text { reinforced concrete }+20 \mathrm{~mm} \text { plasterboard }\end{array}$ & 2.96 \\
\hline Window & Double glazing & 2.80 \\
\hline
\end{tabular}

Table 2 Occupancy schedule

\begin{tabular}{|c|c|c|c|}
\hline \multirow[t]{3}{*}{ Occupants } & $\begin{array}{l}\text { Bedrooms ( } 2 \text { persons for } \mathrm{R} 1 \\
\text { and } 1 \text { person for } \mathrm{R} 3 \text { ) }\end{array}$ & $\begin{array}{l}\text { Weekdays } \\
\text { \&weekends }\end{array}$ & $21: 00-24: 00 ; 0: 00-6: 00$ \\
\hline & Sitting room (3 persons) & Weekdays & 6:00-8:00; 18:00-21:00 \\
\hline & & Weekends & $6: 00-21: 00$ \\
\hline \multirow[t]{3}{*}{$\begin{array}{l}\text { Lighting \& } \\
\text { equipment }\end{array}$} & Bedrooms (R1, R3) & $\begin{array}{l}\text { Weekdays } \\
\& \text { weekends }\end{array}$ & $6: 00-8: 00 ; 21: 00-22: 00$ \\
\hline & Sitting room (R5) & Weekdays & $6: 00-8: 00 ; 18: 00-21: 00$ \\
\hline & & Weekends & $6: 00-21: 00$ \\
\hline
\end{tabular}




\subsection{Solving method of the physical model}

To avoid a large computational effort of solving the 5-room flat model simultaneously, the matrices $\mathrm{C}$, $\mathrm{A}$ of each room are constructed separately and the matrix equations for rooms R1-R5 in the form of equation (8) are solved successively. For the calculation case of free-running room temperatures in section 3.1 as a portion of model validation, the matrices $\mathrm{C}$, A of all the 5 rooms are constructed with all the temperature nodes involving building envelope components and the indoor air. While in the calculations of ideal building heating and cooling loads, the air node is excluded from the matrices $\mathrm{C}, \mathrm{A}$ as well as the vector $\mathrm{b}$ for the functional rooms (R1, R3, R5), because the room target temperature is fixed for the functional rooms $\left(18{ }^{\circ} \mathrm{C}\right.$ for heating and $26{ }^{\circ} \mathrm{C}$ for cooling). The ideal heating and cooling loads of the functional rooms at every time step ' $i$ ' are calculated by equations (13) and (14), respectively.

$$
\begin{gathered}
Q_{h}(i-1)=C_{p, \text { air }} \rho_{\text {air }} V_{\text {air }}\left(t_{h, \text { target }}-t_{\text {air }}(i-1)\right) / \Delta \tau+\sum_{j} h_{\text {in }, \text { wall }} f_{j}\left(t_{h, \text { target }}-\right. \\
\left.t_{\text {wall }, j}(i-1)\right)+C_{p, \text { air }} \rho_{\text {air }} \frac{n_{A C H} \cdot V_{\text {air }}}{3600}\left(t_{h, \text { target }}-t_{a, \text { out }}\right)-Q_{\text {ing,conv }}(i) \\
Q_{c}(i-1)=C_{p, \text { air }} \rho_{\text {air }} V_{\text {air }}\left(t_{\text {air }}(i-1)-t_{c, \text { target }}\right) / \Delta \tau+\sum_{j} h_{\text {in, wall }} f_{j}\left(t_{\text {wall,j }}(i-\right. \\
\left.1)-t_{c, \text { target }}\right)+C_{p, \text { air }} \rho_{\text {air }} \frac{n_{A C H} \cdot V_{\text {air }}}{3600}\left(t_{a, \text { out }}-t_{c, \text { target }}\right)+Q_{\text {ihg,conv }}(i)
\end{gathered}
$$

A complicated Matlab program has been written to implement the 5-room flat model.

Supplementary material of the programs is illustrated in Appendix A. The solver ode15 in Matlab was used to directly solve the set of linear differential equations in Equation

(8). The flow chart of the program algorithm for calculating heating and cooling loads 
under a fixed room temperature is presented in Figure 3.

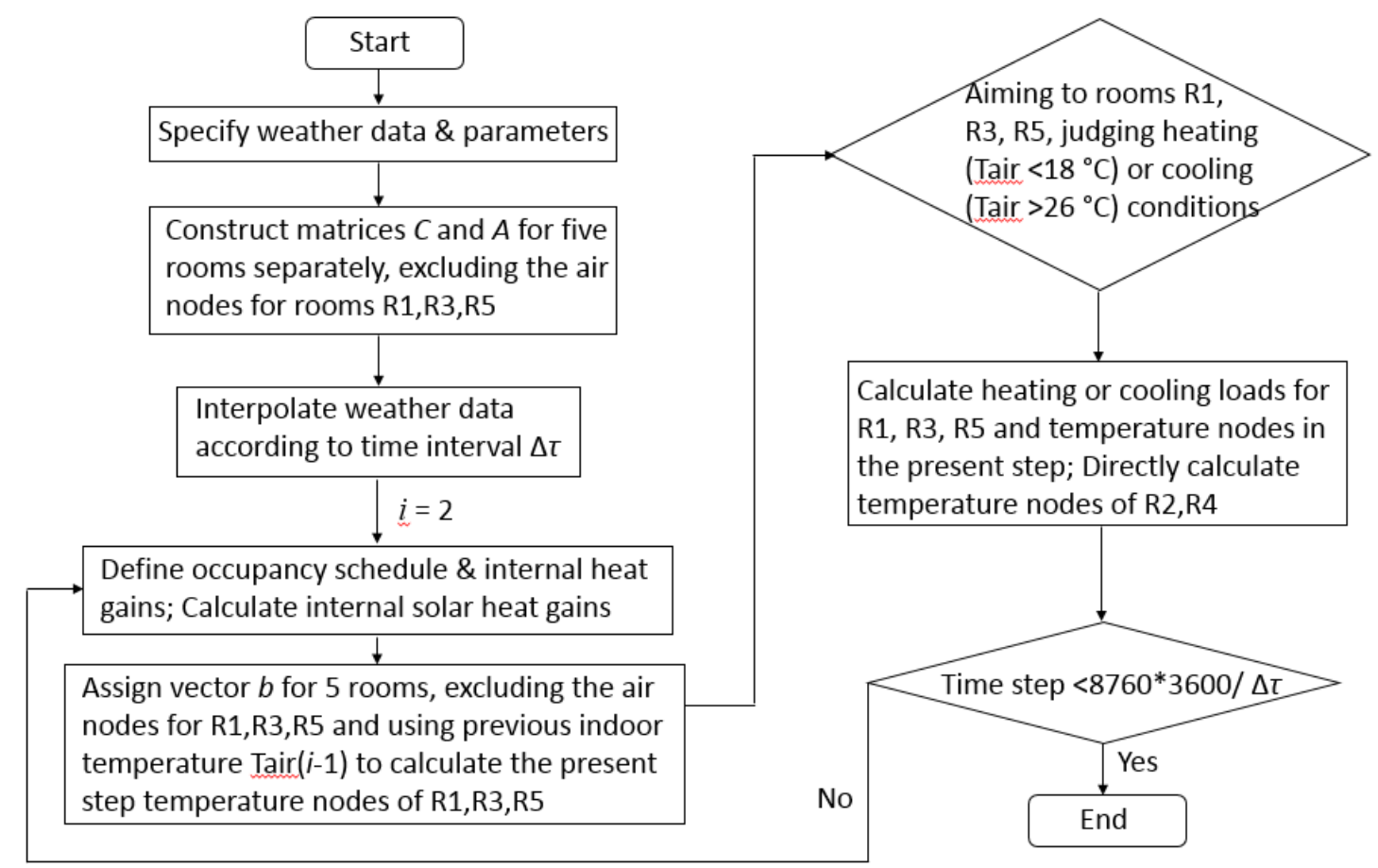

Figure 3 Flow Chart of the Matlab program for calculating ideal building H\&C loads with fixed room target temperatures

\section{Model validation}

Actually, the state-space method has been widely validated for building simulations [ 34 ,

35]. Nevertheless, the case of free-running room temperature and the case of heating loads in the part time pattern based on the benchmark condition (see Table 1) are illustrated to testify the established model using Changsha weather data and $1 \mathrm{~h}$ time interval. As EnergyPlus is internationally acknowledged professional software [8] in the scope, calculation results of the same conditions by EnergyPlus are used as the reference. 


\subsection{Free-running room temperature without consideration of building loads}

Figure 4 gives the comparison of free-running room temperature of R1 between the simulation results of EnergyPlus and the model developed in Matlab program in the benchmark condition. It shows a good agreement between each other with a high relevance coefficient of 0.99 .

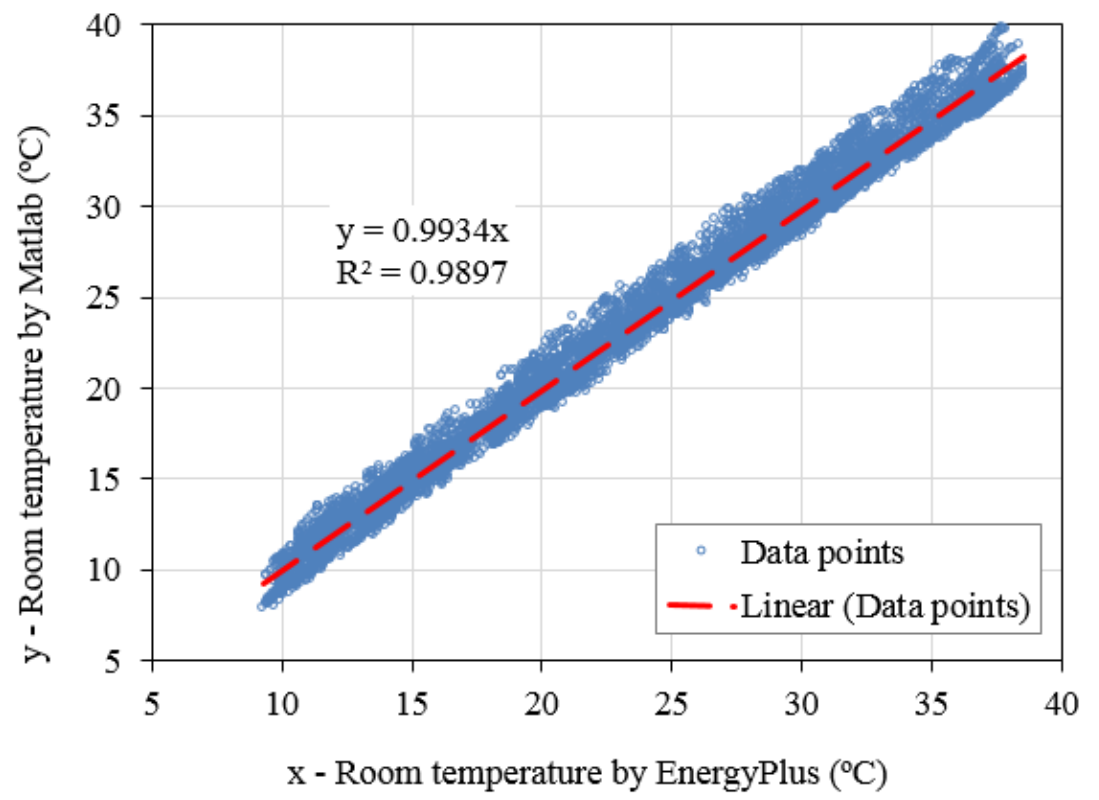

Figure 4 Temperature comparison of room R1 between the calculation results of Matlab program and EnergyPlus

\subsection{Heating loads in the part time pattern}

Figure 5 shows comparison of the calculation results of ideal heating loads for room R1 by the Matlab program and EnergyPlus in the benchmark condition. It also shows a good agreement between the two cases and the relative deviation of statistical total 
building heating loads between the two cases is $4.6 \%$, indicating the established model is effective for further study.

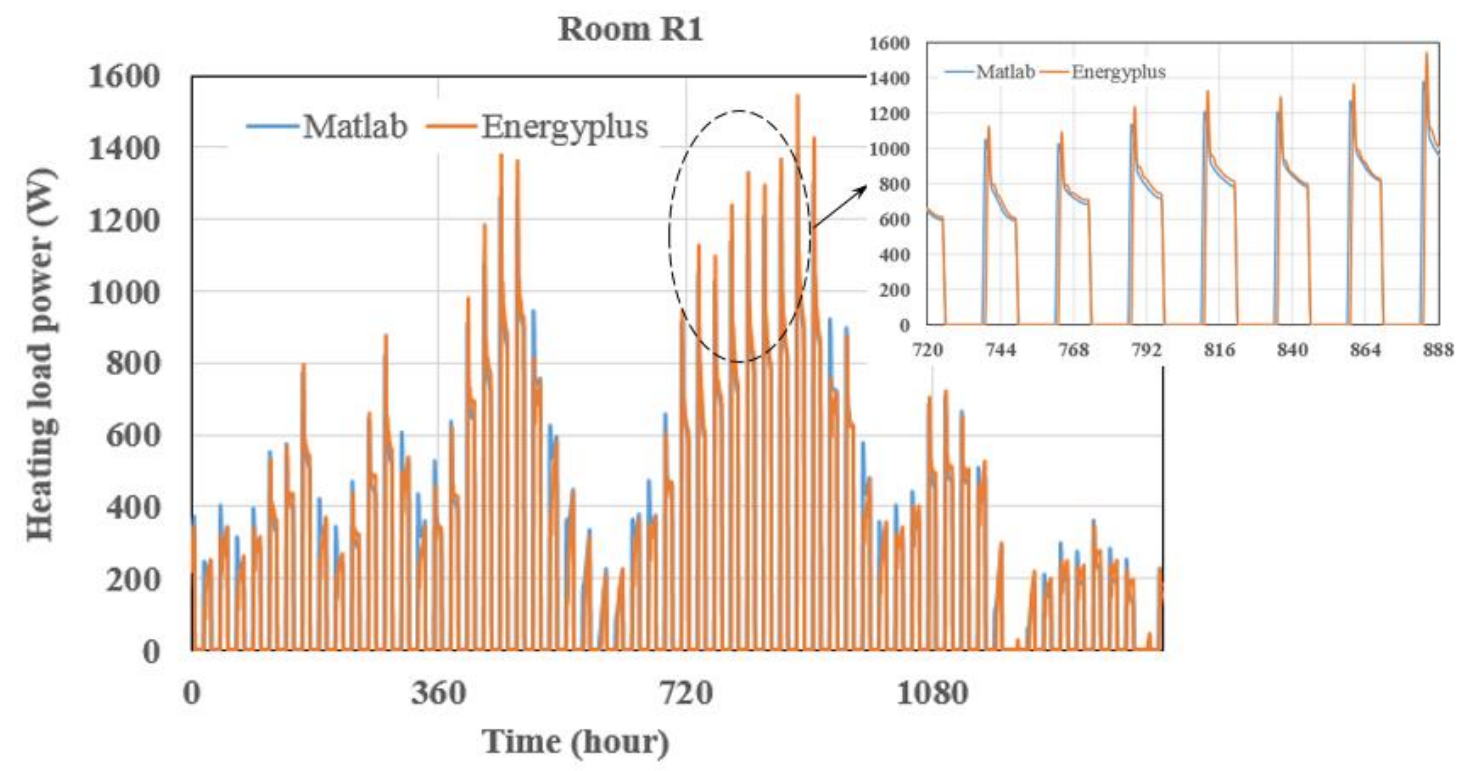

Figure 5 Heating load powers of Room R1 in the part time heating pattern from January to February (the whole year hour number: $0-1416 \mathrm{~h}$ )

\section{Scenario analysis and discussion}

Three representative cities Chongqing, Changsha, Shanghai located at the upstream, middle and downstream of the Yangtze River, respectively, are concerned in full time and part time $\mathrm{H} \& \mathrm{C}$ patterns. The winter heating period from $1^{\text {st }}$ December to $28^{\text {th }}$ February and the cooling period from $15^{\text {th }}$ June to $31^{\text {st }}$ August stipulated in the building code of HSCW zone of China [31] is considered for calculations of building H\&C loads. Referring to the building code, the recommended $U$-value of $0.83 \mathrm{~W} /\left(\mathrm{m}^{2} \mathrm{~K}\right)$ is chosen for case studies. To assess the effectiveness of thermal mass, three representative thermal mass compositions of external walls as well as three thermal insulation 
placements of heavy weight external walls under the same recommended $U$-value are compared.

\subsection{Part-time part-space versus full-time part-space $\mathrm{H} \& \mathrm{C}$ load profiles}

In the full time part space pattern, thermal comfort of three functional rooms (R1, R3, R5, see Figure 2) should be met all the time during $\mathrm{H} \& \mathrm{C}$ periods, while in the part time part space pattern just the occupied hours (see Table 2) should be met with comfort temperature. Ideal sensible building heating/cooling loads for the three cities are calculated in both patterns to make comparisons. The ideal sensible building heating/cooling load is defined as the heat or cold quantity required for maintaining a functional room air temperature at a fixed point. The fixed target temperatures for heating and cooling are chosen as $18{ }^{\circ} \mathrm{C}, 26^{\circ} \mathrm{C}$, respectively, according to the building code [31]. The ideal building loads differ from real building thermal energy consumptions as usually room temperature can not be fixed at a point by specific heating/cooling systems due to room air distribution and system thermal response. Notwithstanding, it is necessary to calculate the ideal building $\mathrm{H} \& \mathrm{C}$ loads for determining the required capacities of $\mathrm{H} \& \mathrm{C}$. Moreover, it makes sense to compare the ideal building loads in different cases as it excludes complicated influences from relevant energy supply systems if concerned.

Table 3 gives the calculation results of ideal sensible $\mathrm{H} \& \mathrm{C}$ loads of the studied building apartment with heavy weight external walls in two $\mathrm{H} \& \mathrm{C}$ patterns with a time interval 
of $1 \mathrm{~h}$ in three typical cities. It's found that the energy saving ratios of heating in part time part space pattern are $25.34-28.13 \%$ compared to those in the full time part space pattern in three cities, while the cooling energy saving ratio of the part time pattern are $28.14-31.75 \%$. Furthermore, it is observed the ideal sensible heating load of Shanghai is somewhat lower than that of Chongqing, although the average outdoor temperature of Shanghai $\left(6.1^{\circ} \mathrm{C}\right)$ during the heating period is lower than that of Chongqing $\left(9.2^{\circ} \mathrm{C}\right)$. Through an examination of the calculation data, it is found this is because the winter solar irradiance resource of Shanghai is more abundant than that of Chongqing in the TMY weather data, contributing to more internal solar heat gains in Shanghai.

Table 3 Total sensible H\&C loads in full time and part time part space patterns in three cities in the $\mathrm{HSCW}$ zone $\left(18{ }^{\circ} \mathrm{C}\right.$ for heating and $26^{\circ} \mathrm{C}$ for cooling)

\begin{tabular}{llll}
\hline Cities & H\&C patterns & $\begin{array}{l}\text { Ideal sensible heating } \\
\text { load }\left(\mathrm{kWh} /\left(\mathrm{m}^{2} \mathrm{a}\right)\right)\end{array}$ & $\begin{array}{l}\text { Ideal sensible cooling } \\
\text { load }\left(\mathrm{kWh} /\left(\mathrm{m}^{2} \mathrm{a}\right)\right)\end{array}$ \\
\hline Chongqing & Full time & 22.04 & 30.13 \\
\cline { 2 - 4 } & Part time & 15.84 & 21.65 \\
\cline { 2 - 4 } & $\begin{array}{l}\text { Energy saving } \\
\text { in part time }\end{array}$ & $28.13 \%$ & $28.14 \%$ \\
\hline Changsha & Full time & 28.34 & 29.45 \\
\cline { 2 - 4 } & Part time & 21.16 & 20.10 \\
\cline { 2 - 4 } & $\begin{array}{l}\text { Energy saving } \\
\text { in part time }\end{array}$ & $25.34 \%$ & $31.75 \%$ \\
\hline Shanghai & Full time & 20.41 & 27.94 \\
\cline { 2 - 4 } & Part time & 15.22 & $29.06 \%$ \\
\cline { 2 - 4 } & $\begin{array}{l}\text { Energy saving ratio } \\
\text { in part time }\end{array}$ & $25.43 \%$ & \\
\hline
\end{tabular}

Note: (1) Calculations based on the benchmark condition; (2) The total flat floor area of $70.2 \mathrm{~m}^{2}$ is used to calculate the H\&C loads.

Although the ideal H\&C loads of the studied building apartment in the part time pattern 
are significantly reduced compared to those in the full time pattern, it is observed that the part time $\mathrm{H} \& \mathrm{C}$ loads profiles are much steeper than those of full time patterns in the three cities. Taking Changsha city as an example, Figure 6 shows comparisons of the total sensible heating load powers of the building apartment in the full time and the part time heating patterns during the period of $2^{\text {nd }}-8^{\text {th }}$ February (the whole year hour number: $768-936$ h), which represents a relatively cold week in Changsha weather data. Heavy weight external walls with both internal and external insulations are considered in the calculations. It is shown that local peak heating loads frequently appear in the part time pattern in Figure 6 due to the intermittent occupancy. When scrutinising heating load profiles of a single functional room (R1, R3 or R5), the profiles in the part time pattern are dramatically steeper than those in the full time pattern, as shown in Figure 7 (a) and (b) for rooms R1, R5, respectively. The case of room R3 is omitted as it's similar to that of room R1 with the same room function. Similar features of peak loads appear in the cooling load profiles in the part time pattern. Figures 7 (c) and (d) give the comparisons of cooling load powers in different cases in a week of extreme hot weather during $1^{\text {st }}-7^{\text {th }}$ July (the whole year hour number: 4344 - $4512 \mathrm{~h}$ ) in Changsha weather data. Local cooling powers in the part time pattern are much higher than those in the full time pattern. It suggests that required capacities of $\mathrm{H} \& \mathrm{C}$ systems in the part time pattern should be much higher than those in the full time pattern. To quantify the required capacities in the two patterns, the typical weeks of relatively cold and extreme hot weather in each city are identified according to continuous 7-day peak loads in relevant $\mathrm{H} \& \mathrm{C}$ periods. The required capacity is 
calculated as the averaged load power of occupied hours in the typical week conditions. Table 4 summarizes the required capacities of H\&C systems in the part time and the full time patterns. It suggests that the required capacities of heat or cool supply systems in the part time pattern should be 1.4-2.1 times as those in the full time pattern in the three cities Chongqing, Changsha, Shanghai.

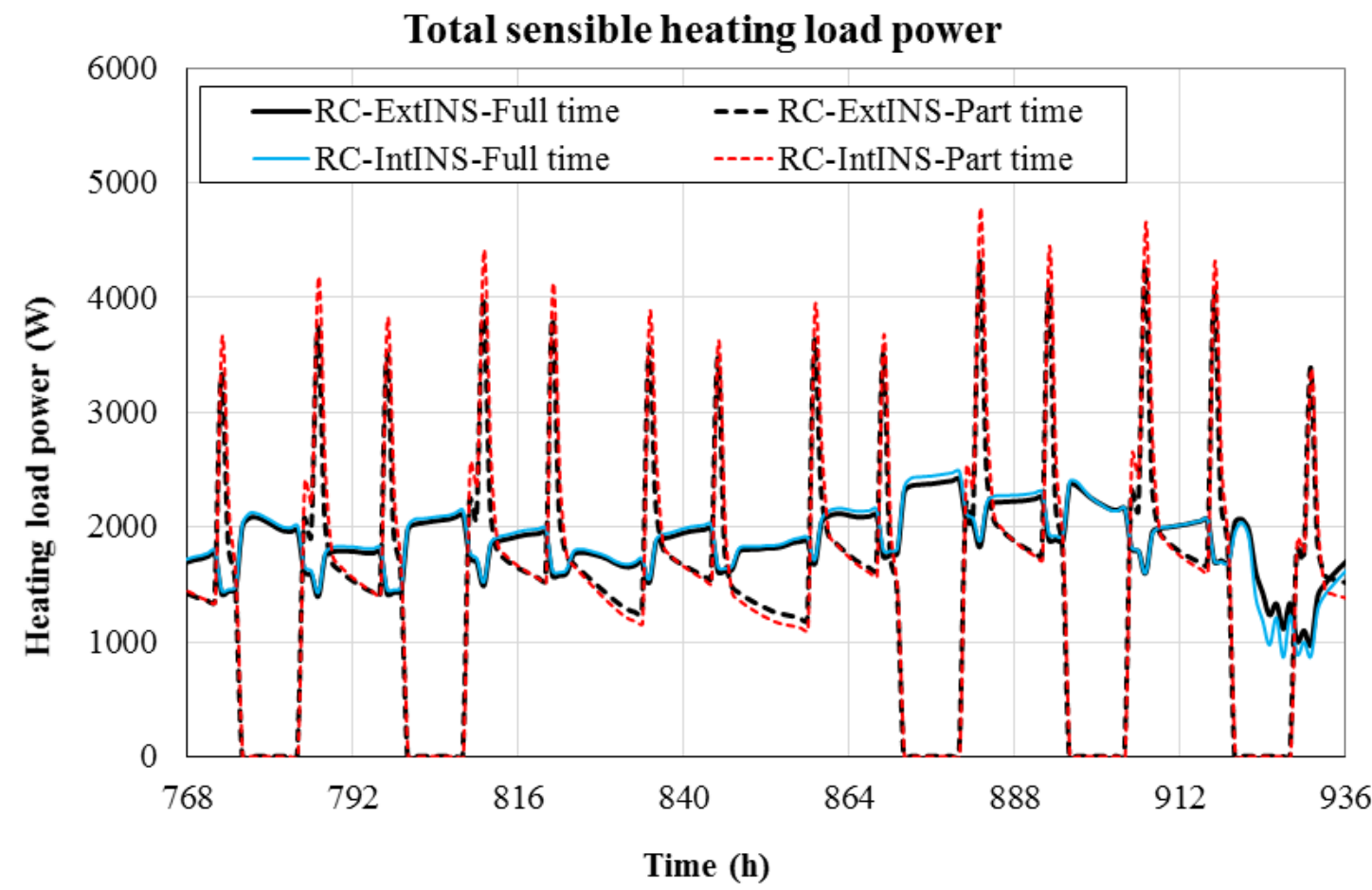

Figure 6 Total sensible heating load powers of the building apartment in full time and part time patterns in a typical week of relatively cold weather $\left(2^{\text {nd }}-8^{\text {th }}\right.$ February; the whole year hour number: $768 \mathrm{~h}-936 \mathrm{~h}$ )

(RC-ExtINS denotes reinforced concrete with external insulation for external walls in the benchmark condition; RC-IntINS denotes internal insulation is used for the reinforced concrete walls) 
(a) Room R1 sensible heating load power

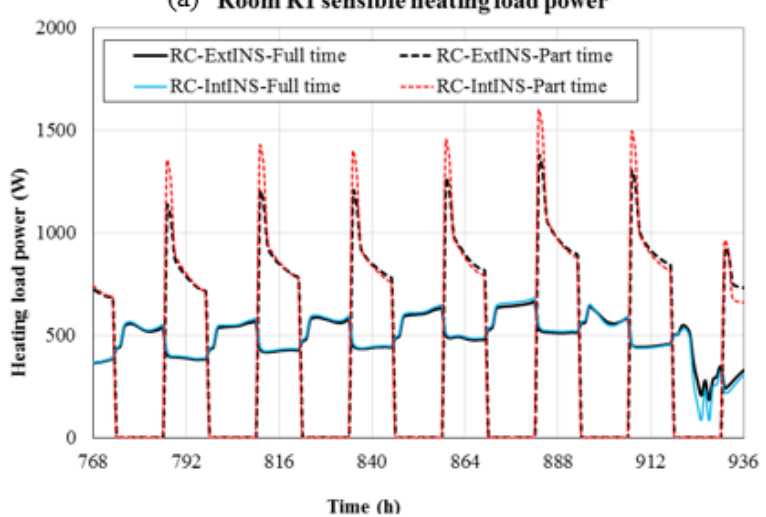

(c) Room R1 cooling load power

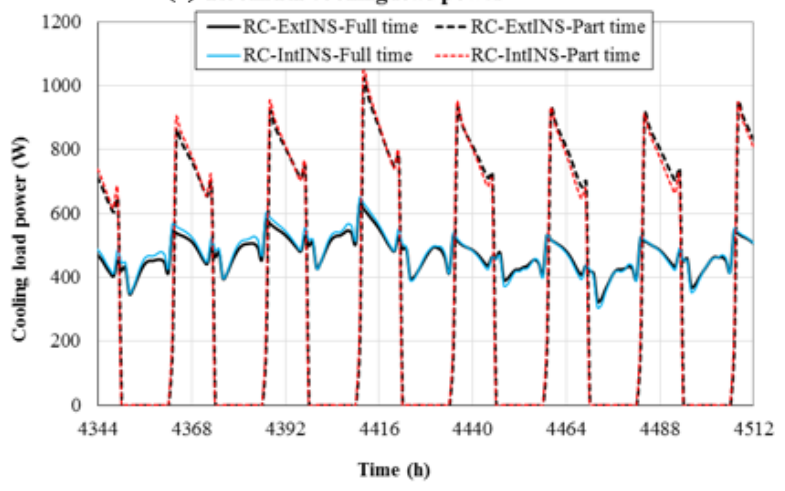

(b) Room R5 sensible heating load power

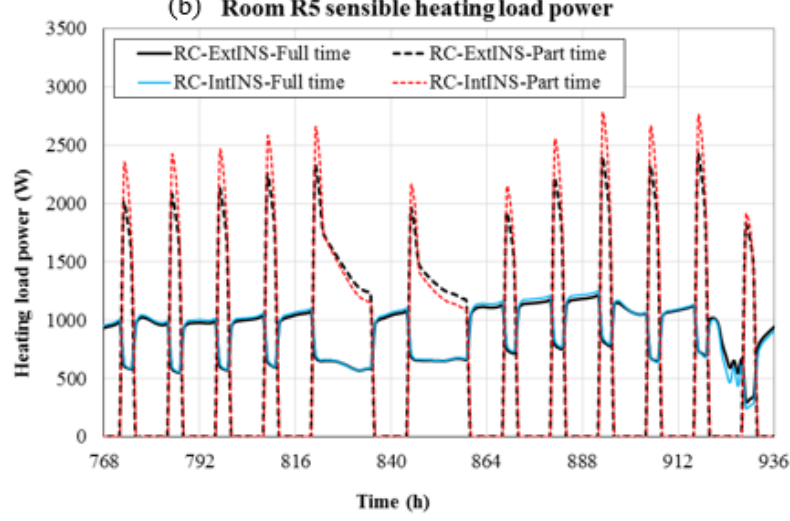

(d) Room R5 cooling load power

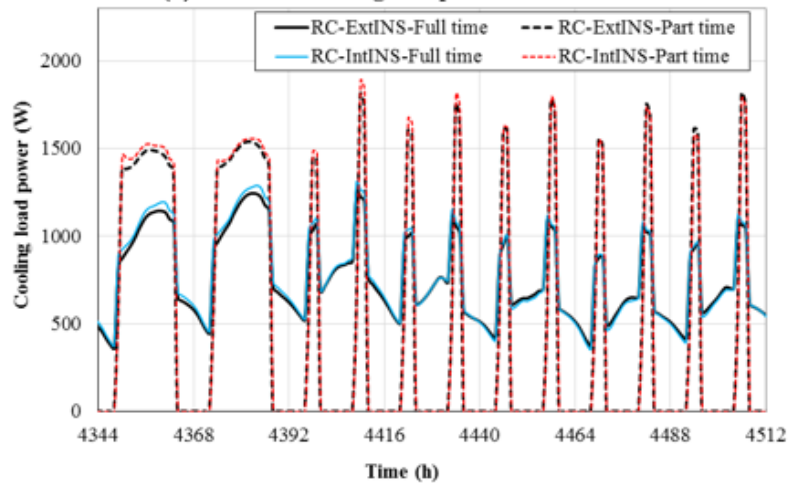

Figure 7 Comparison of sensible $\mathrm{H} \& \mathrm{C}$ loads in full time and part time patterns (a) heating load powers of R1 in a week of relatively cold weather $\left(2^{\text {nd }}-8^{\text {th }}\right.$ February); (b) heating load powers of R5 in a week of relatively cold weather $\left(2^{\text {nd }}-8^{\text {th }}\right.$ February);(c) cooling load powers of R1 in a week of extreme hot weather $\left(1^{\text {st }}-7^{\text {th }} \mathrm{July}\right)$; (d) cooling load powers of R5 in a week of extreme hot weather $\left(1^{\text {st }}-7^{\text {th }} \mathrm{July}\right)$ 
Table 4 Required capacities of heat or cold supply powers for three functional rooms in the studied flat in three different cities in the HSCW zone

\begin{tabular}{|c|c|c|c|c|c|c|c|c|c|c|c|}
\hline \multirow[b]{2}{*}{ Cities } & \multirow[b]{2}{*}{$\begin{array}{c}\text { Compositions } \\
\text { of external } \\
\text { wall }\end{array}$} & \multirow[b]{2}{*}{$\begin{array}{l}\text { Conditions } \\
\text { and typical } \\
\text { week }\end{array}$} & \multicolumn{3}{|c|}{ Full time } & \multicolumn{3}{|c|}{ Part time } & \multicolumn{3}{|c|}{$\begin{array}{c}\text { Power ratio of part } \\
\text { time to full time }\end{array}$} \\
\hline & & & $\begin{array}{l}\text { Required } \\
\text { capacity } \\
\text { of room } \\
\text { R1 (W) }\end{array}$ & $\begin{array}{l}\text { Required } \\
\text { capacity } \\
\text { of room } \\
\text { R3 }(\mathrm{W})\end{array}$ & $\begin{array}{l}\text { Required } \\
\text { capacity } \\
\text { of room } \\
\text { R5 (W) }\end{array}$ & $\begin{array}{l}\text { Required } \\
\text { capacity } \\
\text { of room } \\
\text { R1 (W) }\end{array}$ & $\begin{array}{l}\text { Required } \\
\text { capacity } \\
\text { of room } \\
\text { R3 }(\mathrm{W})\end{array}$ & $\begin{array}{l}\text { Required } \\
\text { capacity } \\
\text { of room } \\
\text { R5 (W) }\end{array}$ & $\begin{array}{l}\text { Ratio } \\
\text { for } \\
\text { room } \\
\text { R1 }\end{array}$ & $\begin{array}{l}\text { Ratio } \\
\text { for } \\
\text { room } \\
\text { R3 }\end{array}$ & $\begin{array}{l}\text { Ratio } \\
\text { for } \\
\text { room } \\
\text { R5 }\end{array}$ \\
\hline \multirow{4}{*}{ Chongqing } & \multirow{2}{*}{$\begin{array}{c}\text { RC+external } \\
\text { insulation }\end{array}$} & $\begin{array}{l}\text { Heating } \\
\text { (19-25 Jan) }\end{array}$ & 280.1 & 297.9 & 512.8 & 508.1 & 520.6 & 922.0 & 1.81 & 1.75 & 1.80 \\
\hline & & $\begin{array}{l}\text { Cooling (29 } \\
\text { Jul-4 Aug) }\end{array}$ & 461.9 & 438.5 & 781.3 & 766.7 & 690.4 & 1446.7 & 1.66 & 1.57 & 1.85 \\
\hline & \multirow{2}{*}{$\begin{array}{l}\text { RC+internal } \\
\text { insulation }\end{array}$} & $\begin{array}{l}\text { Heating } \\
\text { (19-25 Jan) }\end{array}$ & 282.2 & 301.8 & 518.9 & 520.8 & 532.4 & 961.1 & 1.85 & 1.76 & 1.85 \\
\hline & & $\begin{array}{l}\text { Cooling } \\
\text { (29 Jul-4 } \\
\text { Aug) } \\
\end{array}$ & 461.4 & 438.6 & 781.0 & 743.7 & 654.6 & 1420.1 & 1.61 & 1.49 & 1.82 \\
\hline \multirow{4}{*}{ Changsha } & \multirow{2}{*}{$\begin{array}{l}\text { RC+external } \\
\text { insulation }\end{array}$} & $\begin{array}{l}\text { Heating (2- } \\
8 \mathrm{Feb})\end{array}$ & 490.6 & 495.1 & 889.2 & 902.9 & 868.0 & 1693.3 & 1.84 & 1.75 & 1.90 \\
\hline & & $\begin{array}{l}\text { Cooling (1- } \\
7 \text { Jul) }\end{array}$ & 471.2 & 498.7 & 760.6 & 740.8 & 700.0 & 1338.6 & 1.57 & 1.40 & 1.76 \\
\hline & \multirow{2}{*}{$\begin{array}{c}\text { RC+internal } \\
\text { insulation }\end{array}$} & $\begin{array}{l}\text { Heating (2- } \\
8 \mathrm{Feb})\end{array}$ & 491.9 & 501.6 & 897.8 & 926.1 & 892.5 & 1771.9 & 1.88 & 1.78 & 1.97 \\
\hline & & $\begin{array}{l}\text { Cooling (1- } \\
7 \text { Jul) }\end{array}$ & 476.6 & 506.9 & 772.3 & 741.3 & 683.6 & 1370.0 & 1.56 & 1.35 & 1.77 \\
\hline
\end{tabular}




\begin{tabular}{|c|c|c|c|c|c|c|c|c|c|c|c|}
\hline \multirow{4}{*}{ Shanghai } & \multirow{2}{*}{$\begin{array}{c}\text { RC+external } \\
\text { insulation }\end{array}$} & $\begin{array}{l}\text { Heating } \\
(14-20 \text { Jan })\end{array}$ & 361.5 & 413.1 & 704.3 & 742.1 & 818.7 & 1362.2 & 2.05 & 1.98 & 1.93 \\
\hline & & $\begin{array}{l}\text { Cooling } \\
\text { (26 Jun-2 } \\
\text { Jul) } \\
\end{array}$ & 403.6 & 413.5 & 631.8 & 638.0 & 593.2 & 1180.1 & 1.58 & 1.43 & 1.87 \\
\hline & \multirow{2}{*}{$\begin{array}{c}\text { RC+internal } \\
\text { insulation }\end{array}$} & $\begin{array}{l}\text { Heating } \\
\text { (14-20 Jan) }\end{array}$ & 368.9 & 418.8 & 717.8 & 790.3 & 845.3 & 1467.1 & 2.14 & 2.02 & 2.04 \\
\hline & & $\begin{array}{l}\text { Cooling } \\
\text { (26 Jun-2 } \\
\text { Jul) }\end{array}$ & 410.6 & 422.7 & 651.5 & 650.5 & 593.4 & 1211.3 & 1.58 & 1.40 & 1.86 \\
\hline
\end{tabular}




\subsection{Model resolution test with different time intervals}

In real engineering, the room target temperature is usually controlled in a comfort temperature band $\left(18 \pm 1^{\circ} \mathrm{C}\right.$ for heating and $26 \pm 1{ }^{\circ} \mathrm{C}$ for cooling in this study) instead of a fixed point due to room air distribution and energy system response. Response time of relevant energy supply systems is usually less than $30 \mathrm{~min}$. In this case, it is therefore necessary to ascertain the model precision with time intervals smaller than the conventional $1 \mathrm{~h}$ time interval from the perspective of heating/cooling system controls. The original flat model of calculating the ideal building $\mathrm{H} \& \mathrm{C}$ loads has been amended by assigning required capacities of supply powers to 3 functional rooms in order to simulate the conditions of fixed room temperature control bands. In each city, the required capacities of $\mathrm{H} \& \mathrm{C}$ in the cases of external walls with external insulation in Table 4 are adopted as the $\mathrm{H} \& \mathrm{C}$ system supply powers in the amended Matlab program. For the on-off controls of cooling, when the room air temperature is above $27{ }^{\circ} \mathrm{C}$ at a certain iterative step in related room model, the cold supply will be turned on. While the room air temperature is below $25{ }^{\circ} \mathrm{C}$, cold supply will be stopped in the iterative step. For heating, on-off switches of heat supply are similar to those of cooling, by turning on heating at $17{ }^{\circ} \mathrm{C}$ and turning off at $19{ }^{\circ} \mathrm{C}$.

High resolution solutions of the amended model with time intervals of $10 \mathrm{~min}, 15 \mathrm{~min}$, 30 min are implemented to explore the calculation precision of different cases in the full time and part time part space patterns. Changsha weather data is adopted. It is found 
that the simulation deviations of different time intervals in the part time pattern are larger than those in the full time pattern and plus-minus relations of the heating loads in the two patterns are inverse (Table 5). For the part time pattern, the conventional 1hour time interval overestimates building $\mathrm{H} \& \mathrm{C}$ loads by around 7-8\% compared to the case of 10 min time interval. A small time internal of 15-30 min helps to improve resolution of simulations. It is recommended that $15-30$ min time interval should be adopted in the intermittent occupancy. To save computational efforts, a time interval of 30 min has been taken in the following analysis.

Table 5 Comparison of building $\mathrm{H} \& \mathrm{C}$ loads in different time intervals with room temperature control bands of $18 \pm 1^{\circ} \mathrm{C}$ for heating and $26 \pm 1{ }^{\circ} \mathrm{C}$ for cooling in Changsha climate

\begin{tabular}{|c|c|c|c|c|c|}
\hline $\begin{array}{l}\mathrm{H} \& \mathrm{C} \\
\text { patterns }\end{array}$ & $\begin{array}{l}\text { Time } \\
\text { interval } \\
(\Delta \tau)\end{array}$ & $\begin{array}{l}\text { Sensible } \\
\text { heating load } \\
\left(\mathrm{kWh} /\left(\mathrm{m}^{2} \mathrm{a}\right)\right)\end{array}$ & $\begin{array}{l}\text { Sensible } \\
\text { cooling load } \\
\left(\mathrm{kWh} /\left(\mathrm{m}^{2} \mathrm{a}\right)\right)\end{array}$ & $\begin{array}{l}\text { Relative } \\
\text { deviation of } \\
\text { heating } \\
\text { load }\end{array}$ & $\begin{array}{l}\text { Relative } \\
\text { deviation of } \\
\text { cooling } \\
\text { load }\end{array}$ \\
\hline \multirow{4}{*}{$\begin{array}{l}\text { Full } \\
\text { time }\end{array}$} & $1 \mathrm{~h}$ & 24.34 & 32.01 & Benchmark & Benchmark \\
\hline & $30 \mathrm{~min}$ & 25.12 & 31.07 & $3.21 \%$ & $-2.92 \%$ \\
\hline & $15 \mathrm{~min}$ & 25.53 & 30.77 & $4.89 \%$ & $-3.87 \%$ \\
\hline & $10 \mathrm{~min}$ & 25.50 & 30.74 & $4.78 \%$ & $-3.96 \%$ \\
\hline \multirow{4}{*}{$\begin{array}{l}\text { Part } \\
\text { time }\end{array}$} & $1 \mathrm{~h}$ & 17.85 & 24.88 & Benchmark & Benchmark \\
\hline & $30 \mathrm{~min}$ & 17.09 & 23.40 & $-4.26 \%$ & $-5.95 \%$ \\
\hline & $15 \mathrm{~min}$ & 16.67 & 22.83 & $-6.58 \%$ & $-8.24 \%$ \\
\hline & $10 \mathrm{~min}$ & 16.62 & 22.82 & $-6.91 \%$ & $-8.25 \%$ \\
\hline
\end{tabular}

\subsection{Impact of different thermal mass compositions of external walls}

To explore the thermal mass impact of external wall on the building energy demands, 
three representative compositions of external walls with different thermal mass (heavy weight, medium weight, light weight) listed in Table 6 are considered for contrast. The thickness of each layer is assigned considering the recommended $U$-value of 0.83 $\mathrm{W} /\left(\mathrm{m}^{2} \mathrm{~K}\right)$. Thermal properties of the materials are available in [38].

Table 6 Three representative thermal mass compositions of external walls $(U=0.83$

\begin{tabular}{llll}
$\begin{array}{l}\left.\mathrm{W} /\left(\mathrm{m}^{2} \mathrm{~K}\right)\right) \\
\begin{array}{l}\text { External } \\
\text { wall type }\end{array}\end{array}$ & $\begin{array}{l}\text { Composition (from external to internal } \\
\text { wall) }\end{array}$ & $\begin{array}{l}\text { Mass } \\
\left(\mathrm{kg} / \mathrm{m}^{2}\right)\end{array}$ & $\begin{array}{l}\text { Thermal capacity } \\
\left(\mathrm{kJ} /\left(\mathrm{m}^{2} \mathrm{~K}\right)\right)\end{array}$ \\
\hline $\begin{array}{l}38.7 \mathrm{~mm} \text { EPS insulation }+15 \mathrm{~mm} \text { cement } \\
\text { Heavy } \\
\text { weight }\end{array}$ & $\begin{array}{l}\text { mortar }+240 \mathrm{~mm} \text { reinforced Concrete } \\
(\mathrm{RC})+15 \mathrm{~mm} \text { plasterboard }\end{array}$ & 644.2 & 590.4 \\
\hline $\begin{array}{l}\text { Medium } \\
\text { weight }\end{array}$ & $\begin{array}{l}\text { concrete block (ACB) }+15 \quad \mathrm{~mm} \text { cement mortar }+196.5 \mathrm{~mm} \text { aerated } \\
\text { plasterboard }\end{array}$ & 177.1 & 176.8 \\
\hline $\begin{array}{l}\text { Light } \\
\text { weight }\end{array}$ & $\begin{array}{l}10 \mathrm{~mm} \text { stainless steel plate+47.6 mm EPS } \\
\text { insulation }+10 \mathrm{~mm} \text { stainless steel plate }\end{array}$ & 157.9 & 80.8 \\
\hline
\end{tabular}

\subsubsection{Ideal building H\&C loads and operative temperatures}

Figure 8 provides the comparison of ideal total sensible cooling load powers in the cases of three representative thermal mass compositions in the full time cooling pattern from $15^{\text {th }}$ June to $31^{\text {st }}$ August (the whole year hour number: $3960-5832$ h). The ideal total building cooling loads for the three thermal mass cases are close to each other with a deviation of around 1\%. Figure 9 (a) and (b) displays minor differences at local times in a week of extreme hot weather $\left(1^{\text {st }}-7^{\text {th }}\right.$ July $)$ and a week of non-extreme hot weather $\left(7^{\text {th }}-13^{\text {th }}\right.$ August $)$ in Changsha climate. The light weight walls tend to lead the maximum cooling load power in very hot weather, while it results in the minimum 
cooling load power in non-extreme hot weather. It indicates that low thermal mass (light weight wall) is more climate-dependent compared to high thermal mass.

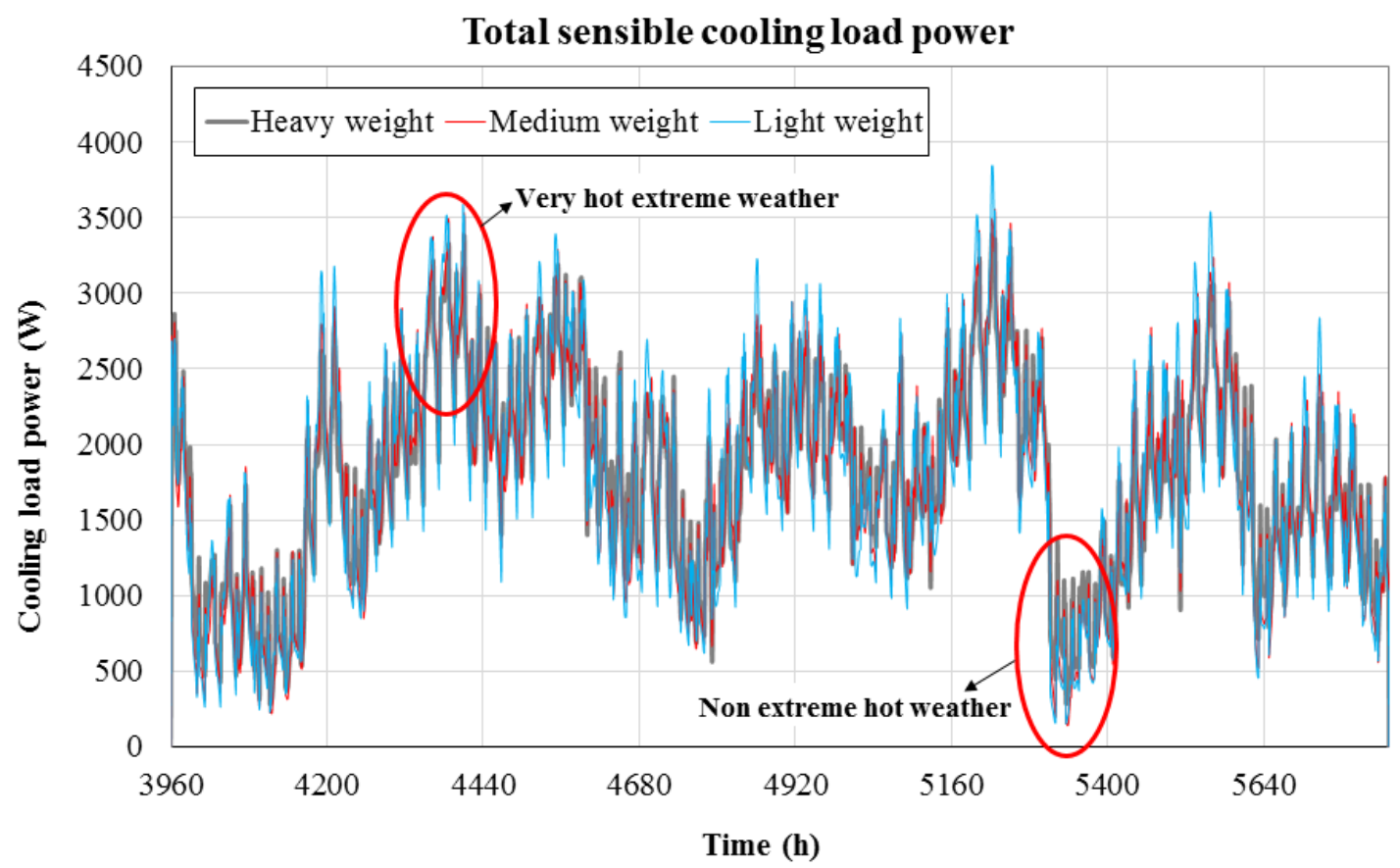

Figure 8 Total sensible cooling load powers of three thermal mass cases in the full time pattern during cooling period $\left(15^{\text {th }}\right.$ June $-31^{\text {st }}$ August; the whole year hour number: 3960 - 5832 h) in Changsha climate

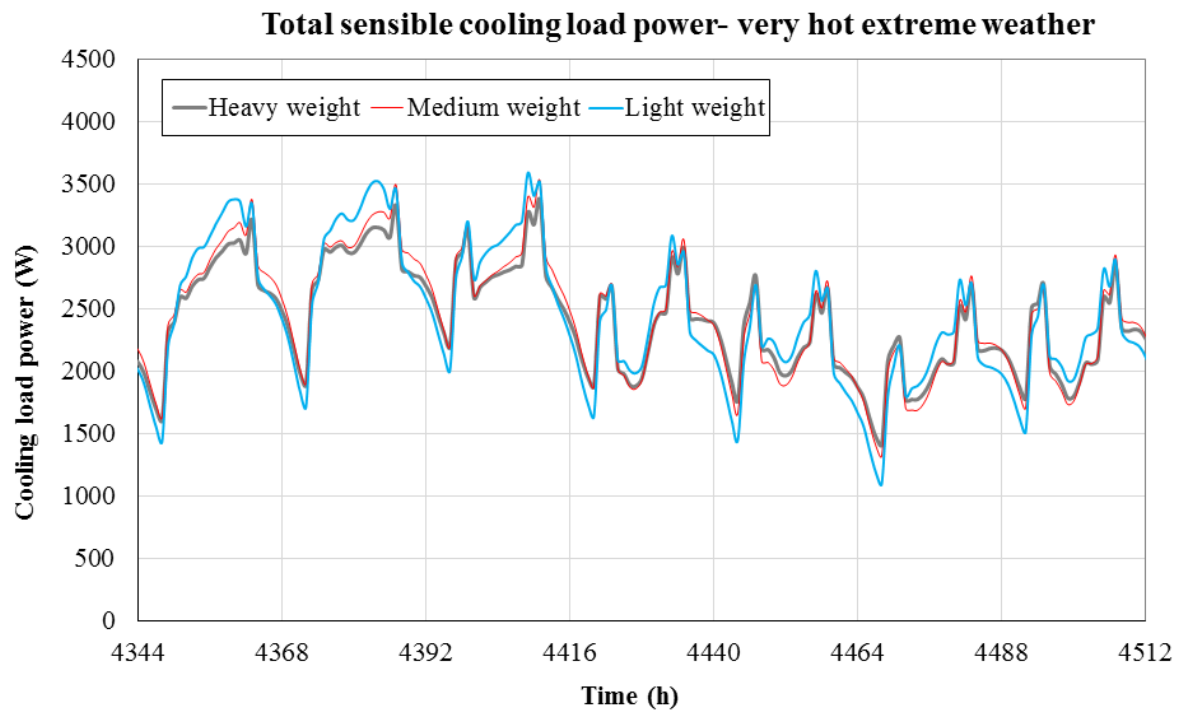

(a) 


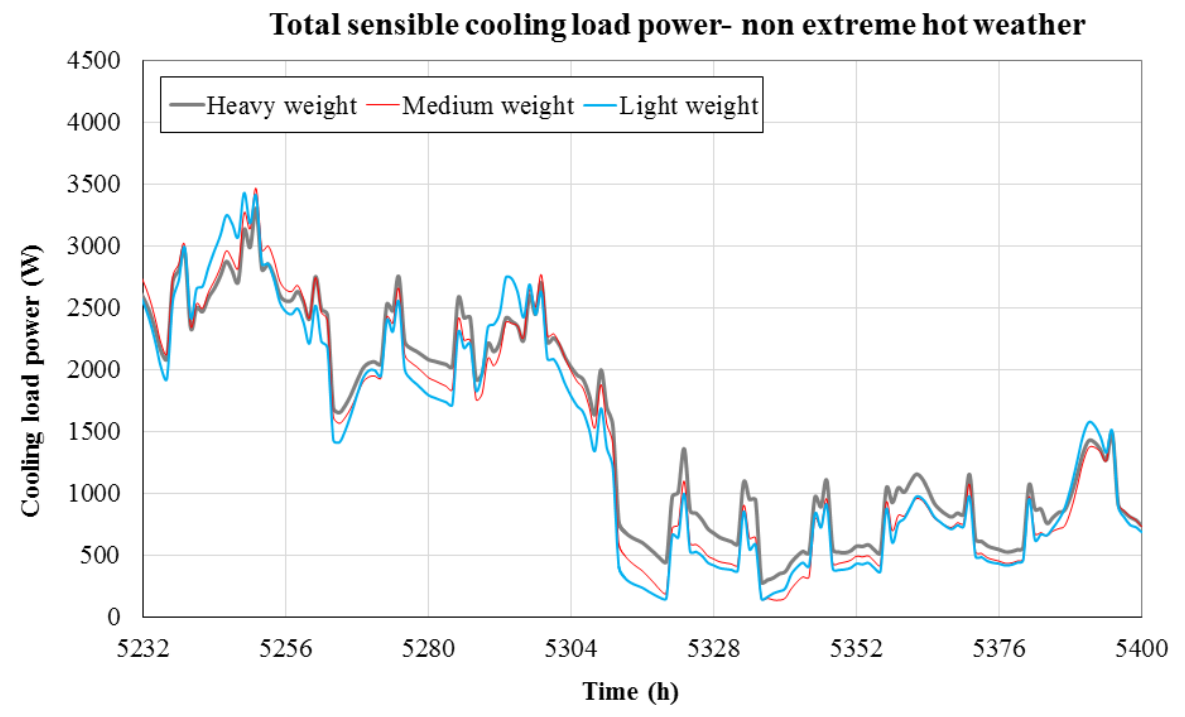

(b)

Figure 9 Total sensible cooling load powers in full time cooling pattern in Changsha climate (a) in a week of extreme hot weather $\left(1^{\text {st }}-7^{\text {th }}\right.$ July); (b) in a week of nonextreme hot weather $\left(7^{\text {th }}-13^{\text {th }}\right.$ August $)$

Although no significant difference is observed in the ideal building H\&C loads for different thermal mass compositions, the mean radiant temperatures of inner wall surfaces in different cases are found to be different. The mean radiant temperature is calculated by the Averaged Unheated/Uncooled Surface Temperature (AUST) of room inner wall surfaces given in Equation (15) [42]. Thus, the operative temperature consisting of the AUST and the air temperature will be different for different thermal mass compositions. The room operative temperature given in Equation (16) represents occupant perceived temperature and should be taken as the indicator of thermal comfort temperature [29, 30]. Figure 10 (a) shows the AUST of Room 1 under different thermal mass during the cooling period $\left(15^{\text {th }}\right.$ June $-31^{\text {st }}$ August $)$ in Changsha climate and Figure 10 (b) gives the development of room operative temperature. It can be seen that the 
AUST and the room operative temperature in the case of light weight walls fluctuate more intensively with a larger amplitude than the other two cases. Variations of Room 1 operative temperature in an enlarged view of a week of extreme hot weather $\left(1^{\text {st }}-7^{\text {th }}\right.$ July) is shown in Figure 11. The fluctuation of room operative temperature with low thermal mass (light weight or medium weight) in the figure is evident although the maximum temperature difference is only $0.3{ }^{\circ} \mathrm{C}$. The present discussion is based on the assumption of an ideal building cooling load aimed to obtain a fixed room temperature at $26{ }^{\circ} \mathrm{C}$. In real engineering, the room target temperature is usually under control in a comfort temperature band $\left(18 \pm 1{ }^{\circ} \mathrm{C}\right.$ for heating and $26 \pm 1{ }^{\circ} \mathrm{C}$ for cooling in this study) instead of a fixed point due to room air distribution and energy system response. When the room target temperature is controlled to be variable in a temperature band rather than a fixed value, the fluctuation effect of low thermal mass will be amplified, probably resulting in discomfort operative temperature at some local time. The amplified effect will be explained in detail in the next section 4.3.2. Thermal mass effect in the part time pattern will also be explained further.

$$
A U S T=\sum_{j=1}^{n} F_{i, j} T_{j}
$$

where $F_{i, j}$ is the view factor of radiative heat transfer from wall surface ' $i$ ' to surface ' $j$ '.

$$
T_{o p}=\frac{h_{c o n v} T_{a i r}+h_{\text {rad }} \cdot A U S T}{h_{c o n v}+h_{\text {rad }}}
$$




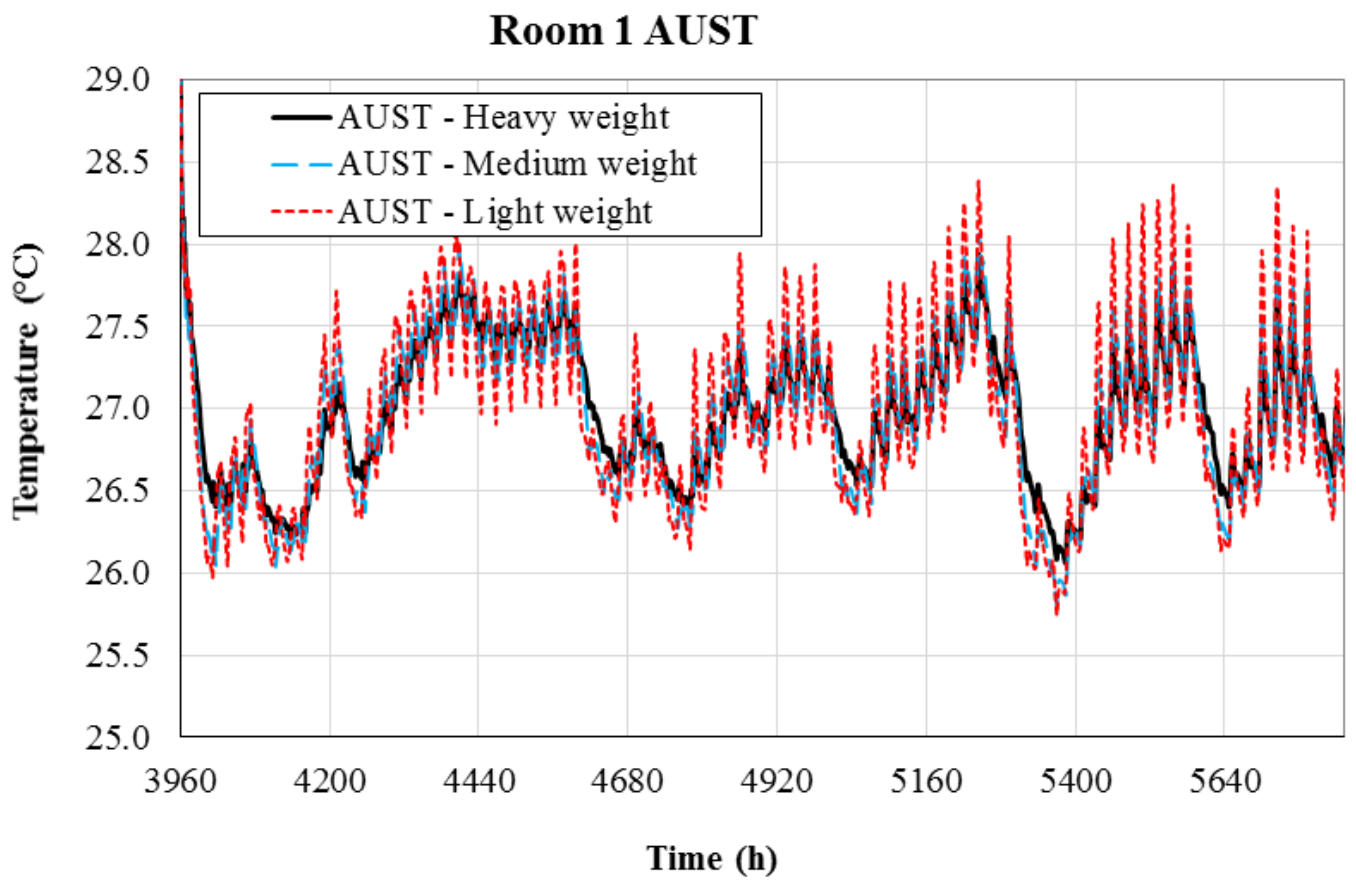

(a)

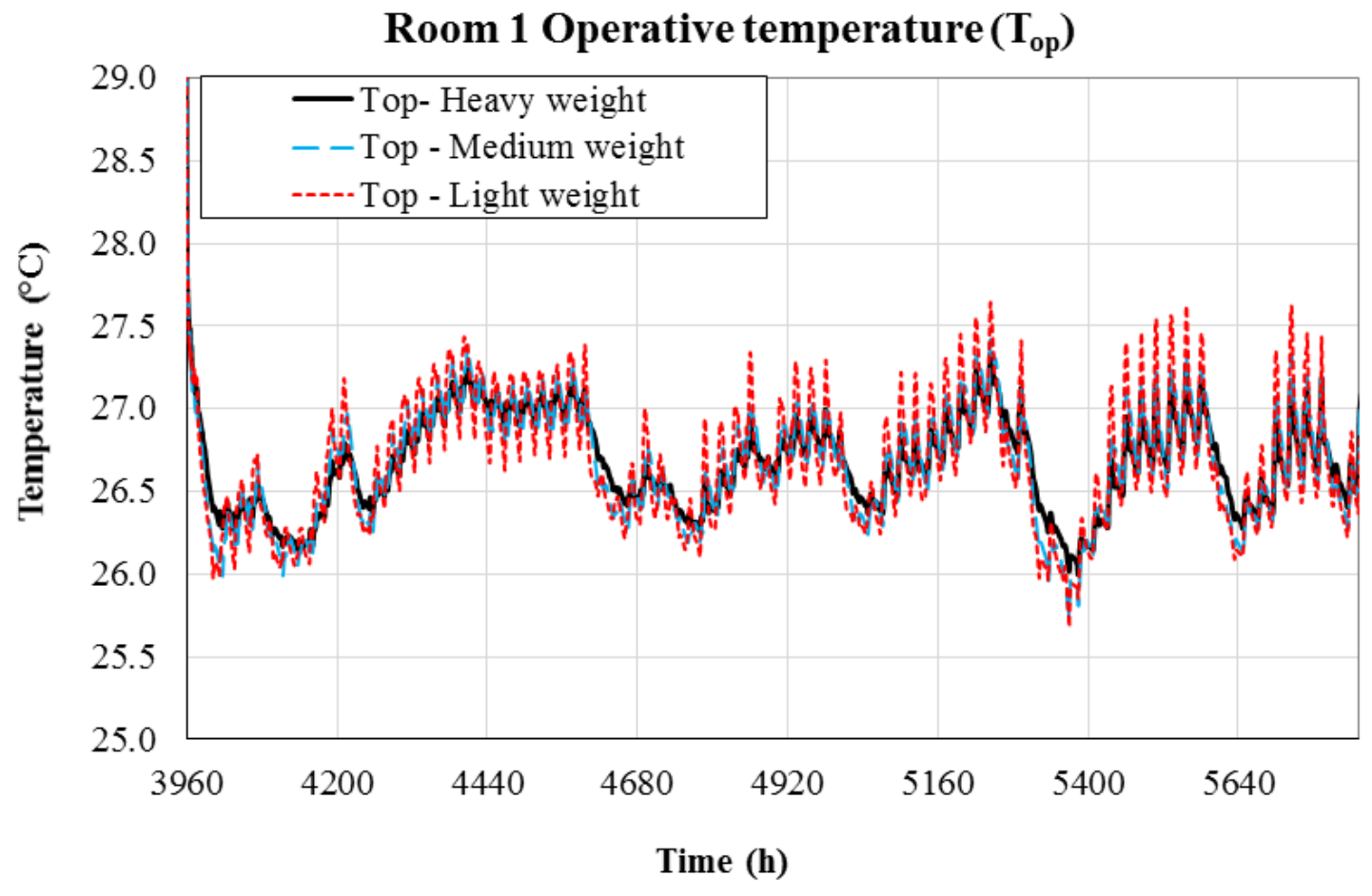

Figure 10 (a) AUST (Averaged Uncooled Surface Temperature); (b) Operative temperature of Room R1 under different thermal mass in full time pattern during the cooling period $\left(15^{\text {th }}\right.$ June $-31^{\text {st }}$ August; the whole year hour number: $\left.3960-5832 \mathrm{~h}\right)$ in Changsha climate 


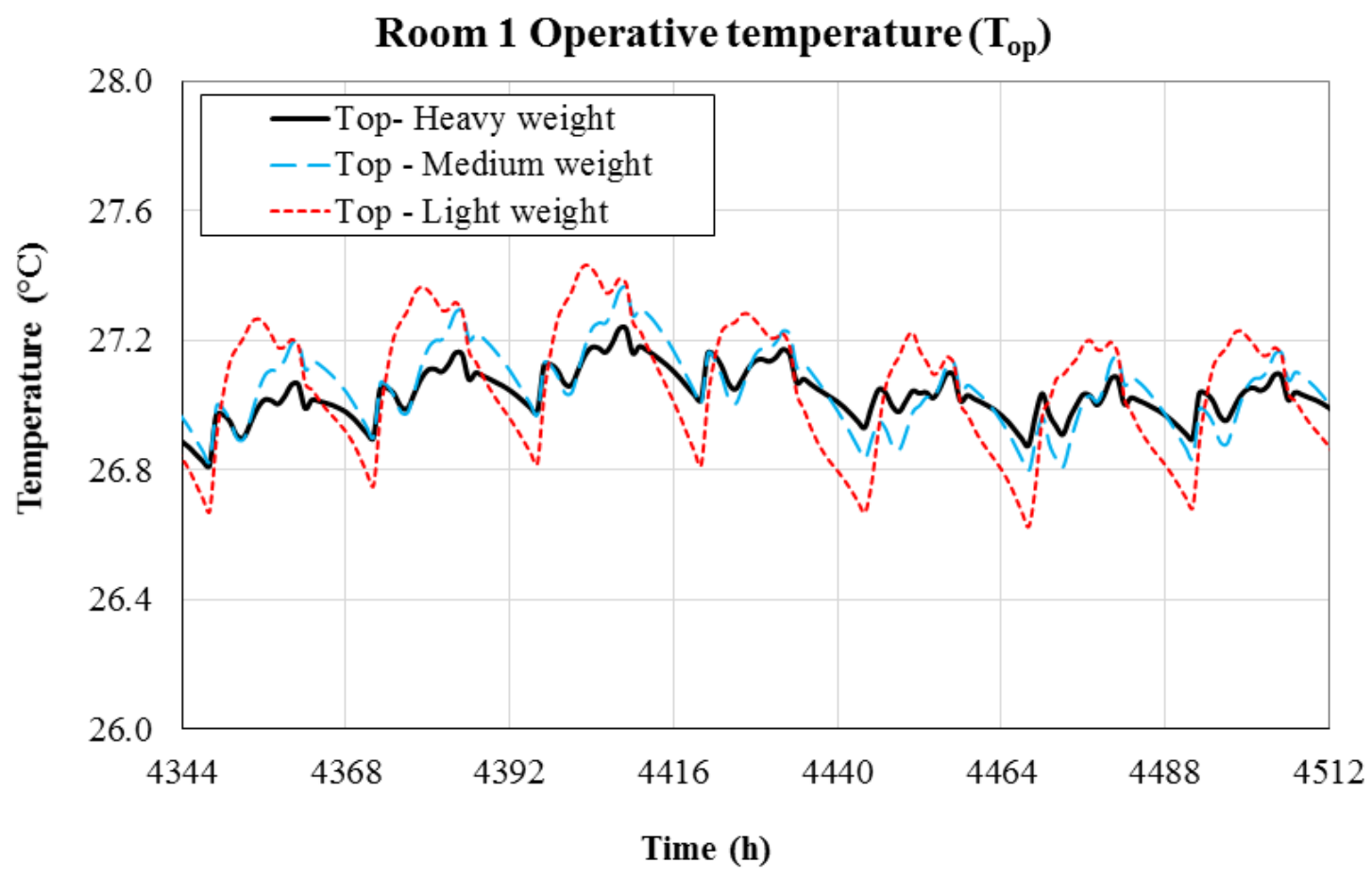

Figure 11 Operative temperature of Room R1 under different thermal mass in a week of extreme hot weather $\left(1^{\text {st }}-7^{\text {th }} \mathrm{July}\right.$; the whole year hour number: $\left.4344-4512 \mathrm{~h}\right)$ in Changsha climate

\subsubsection{Comparison of room thermal comfort controls with different thermal mass in the full time pattern}

The amended model described in section 4.2 with fixed temperature control bands is used to calculate room operative temperatures for the cases of different thermal mass compositions from the perspective of system control. In each $\mathrm{H} \& \mathrm{C}$ pattern and city climate, the required capacities in the benchmark condition (see Table 4) are chosen for the functional rooms for three types of thermal mass composition walls. Figure 12 gives the operative temperature of Room R1 with the cooling temperature control band of $26 \pm 1{ }^{\circ} \mathrm{C}$ under different thermal mass in a week of extreme hot weather in Changsha 
climate $\left(1^{\text {st }}-7^{\text {th }}\right.$ July). Even in the very hot weather conditions, the room operative temperature in the case of heavy weight walls with external insulation are below $28{ }^{\circ} \mathrm{C}$ and thermal comfort in the case is better. The operative temperature in the case of light weight walls at local time is above $28^{\circ} \mathrm{C}$ and the maximum operative temperature difference relative to the heavy weight case exceeds $1{ }^{\circ} \mathrm{C}$. It suggests low thermal mass may result in overheating in summer in the case. To improve the room thermal comfort in the cooling mode with light weight walls, a lower room target temperature should be set (e.g. $24{ }^{\circ} \mathrm{C}$ ) and a larger capacity of the cooling power than the present condition needs to be matched. Undoubtedly, this will increase cooling energy consumption. Furthermore, the adoption of larger capacities of cooling (or heating) units will raise the problem of reasonable system operation strategies in part load conditions in order to avoid frequent start-and-stop of the units. With regard to the heating mode, Figure 13 shows the operative temperature of Room R1 with the heating temperature control band of $18 \pm 1{ }^{\circ} \mathrm{C}$ under different thermal mass in four days of relatively cold weather $\left(4^{\text {th }}-7^{\text {th }}\right.$ February) in Changsha climate. In some hours the operative temperatures in the case of light or medium weight walls are lower than those of heavy weight walls. It suggests that light weight walls can result in worse room thermal comfort than heavy weight walls at relatively cold weather conditions. Hence, even under the same nominal U-value of external walls, thermal comfort of the buildings constructed with relatively light weight external walls is more complex to meet in extreme hot weather and relatively cold weather compared to that of the buildings with heavy weight external walls. This is mainly because a more intensive fluctuation of mean radiant temperature 
on the inner surfaces of external walls. In this regard, using light weight external walls will increase the complexity of thermal comfort control in extreme hot or very cold weather and larger capacities of heat or cold supply powers are needed in comparison to the case of heavy weight walls.

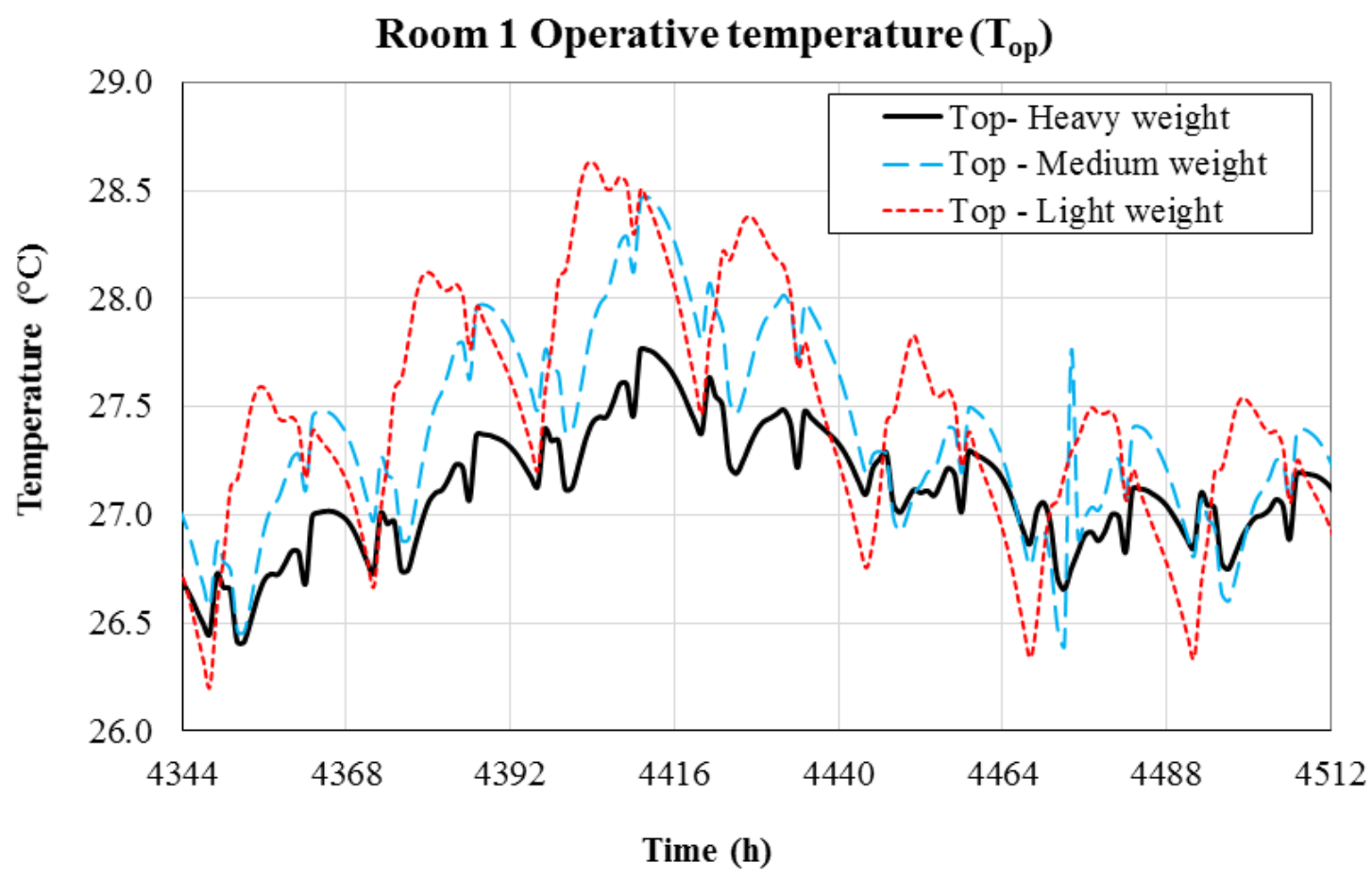

Figure 12 Operative temperature of room R1 with a cooling temperature control band $\left(26 \pm 1{ }^{\circ} \mathrm{C}\right)$ under different thermal mass in a week of extreme hot weather $\left(1^{\text {st }}-7^{\text {th }} \mathrm{July}\right.$; the whole year hour number: $4344-4512$ h) in Changsha climate 


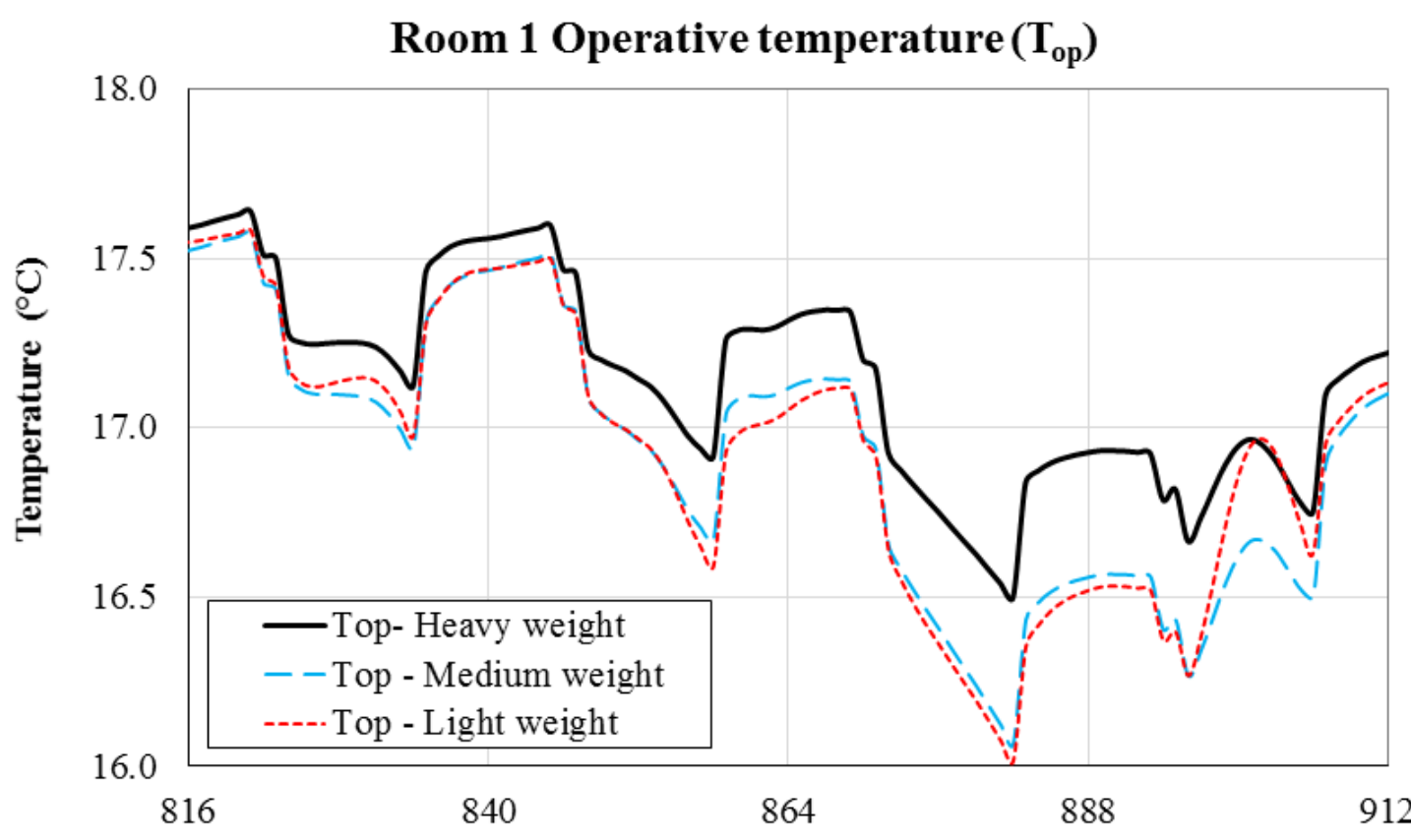

Time (h)

Figure 13 Operative temperature of room R1 with a heating temperature control band $\left(18 \pm 1^{\circ} \mathrm{C}\right)$ under different thermal mass in four days of relatively cold weather $\left(4^{\text {th }}-7^{\text {th }}\right.$ February; the whole year hour number: 816 - 912 h) in Changsha climate

\subsubsection{Comparison of room thermal comfort controls with different thermal mass in the part time pattern}

In the part time pattern, only the room thermal comfort in the occupied hours needs to be concerned. Figure 14 gives the operative temperature of Room R1 with the temperature control band of $26 \pm 1{ }^{\circ} \mathrm{C}$ under different thermal mass in the part time pattern on two continuously hot days $\left(1^{\text {st }}-2^{\text {th }}\right.$ July; the whole year hour number: $4344-$ 4392 h) in Changsha climate. The time slots with the occupied indicator ' 1 ' denote the occupied hours. Similar to the cases of thermal mass in the full time pattern, room thermal comfort in terms of the operative temperature in the occupied hours for the case of light or medium weight walls is worse than that in the case of heavy weight walls in 
an extremely hot weather. Room thermal comfort of heating in the former case are also worse than that in the latter case in a relatively cold weather in the part time pattern and no comparative chart is provided here for simplification.

Besides, it's found the thermal comfort in terms of the operative temperature in occupied hours in the part time pattern is worse than that in the full time pattern when comparing the magnitudes of operative temperatures in Figures 12 and 14, even if the same room temperature control band $\left(26 \pm 1^{\circ} \mathrm{C}\right)$ is considered in both patterns. This is due to higher mean radiant temperatures of wall inner surfaces in the part time pattern. To make the room thermal comfort in the part time pattern close to that in the full time pattern, a lower temperature control band $\left(24 \pm 1^{\circ} \mathrm{C}\right)$ in the part time pattern is needed as illustrated in Figure 15 (in the benchmark condition) and a larger cooling capacity (1.23 times as the case of temperature control band $26 \pm 1^{\circ} \mathrm{C}$ ) should be matched. For the case of heating, worse thermal comfort state is found for the part time pattern compared to that of the full time pattern in relatively cold weather. It suggests thermal comfort in the part time pattern is worse than that in the full time pattern under the same temperature control band. When low thermal mass walls are used, it will increase the complexity of room thermal comfort control. 


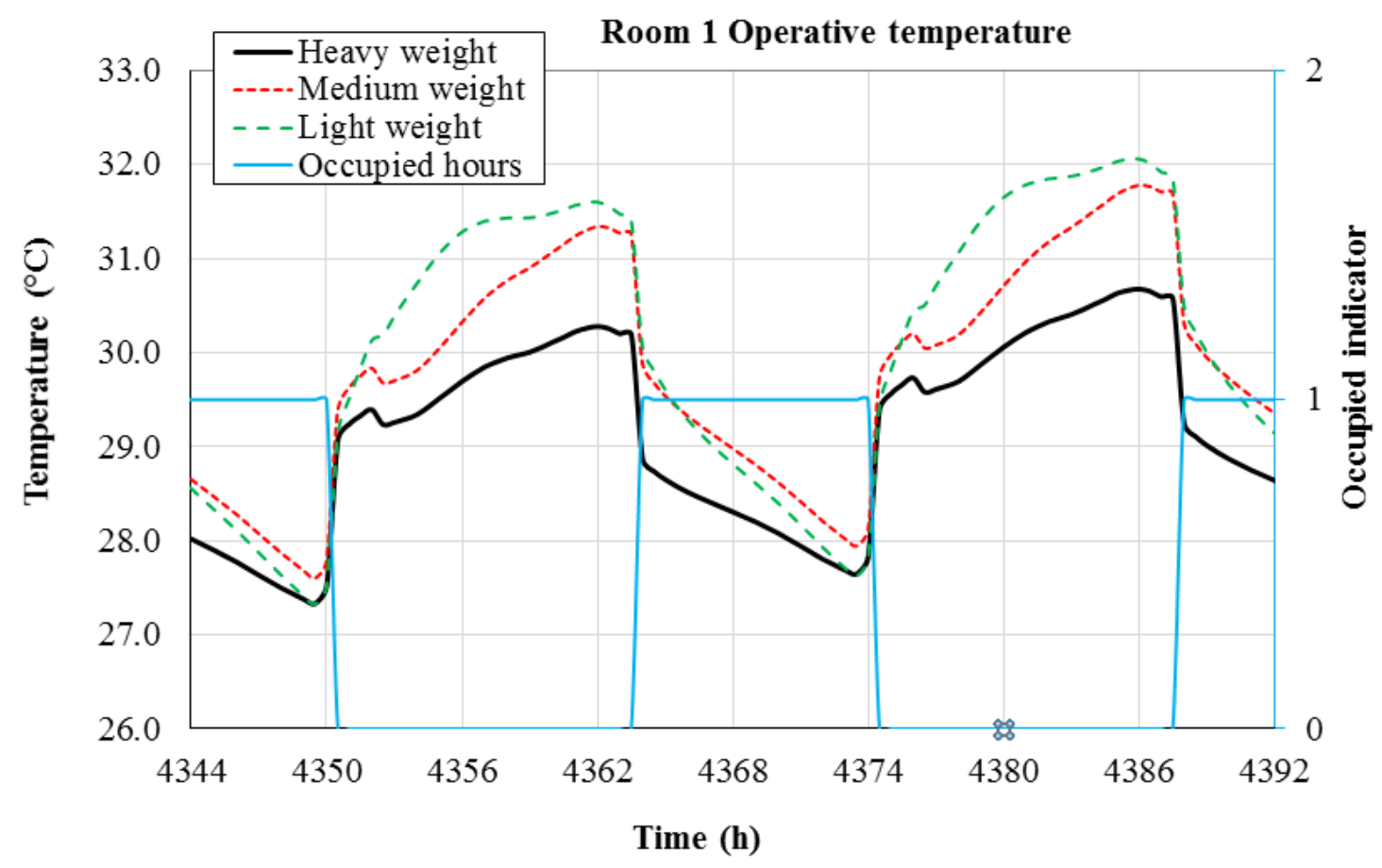

Figure 14 Operative temperature of room R1 with a cooling temperature control band $\left(26 \pm 1{ }^{\circ} \mathrm{C}\right)$ under different thermal mass in the part time pattern on two continuously hot days ( $1^{\text {st }}-2^{\text {th }}$ July) in Changsha climate

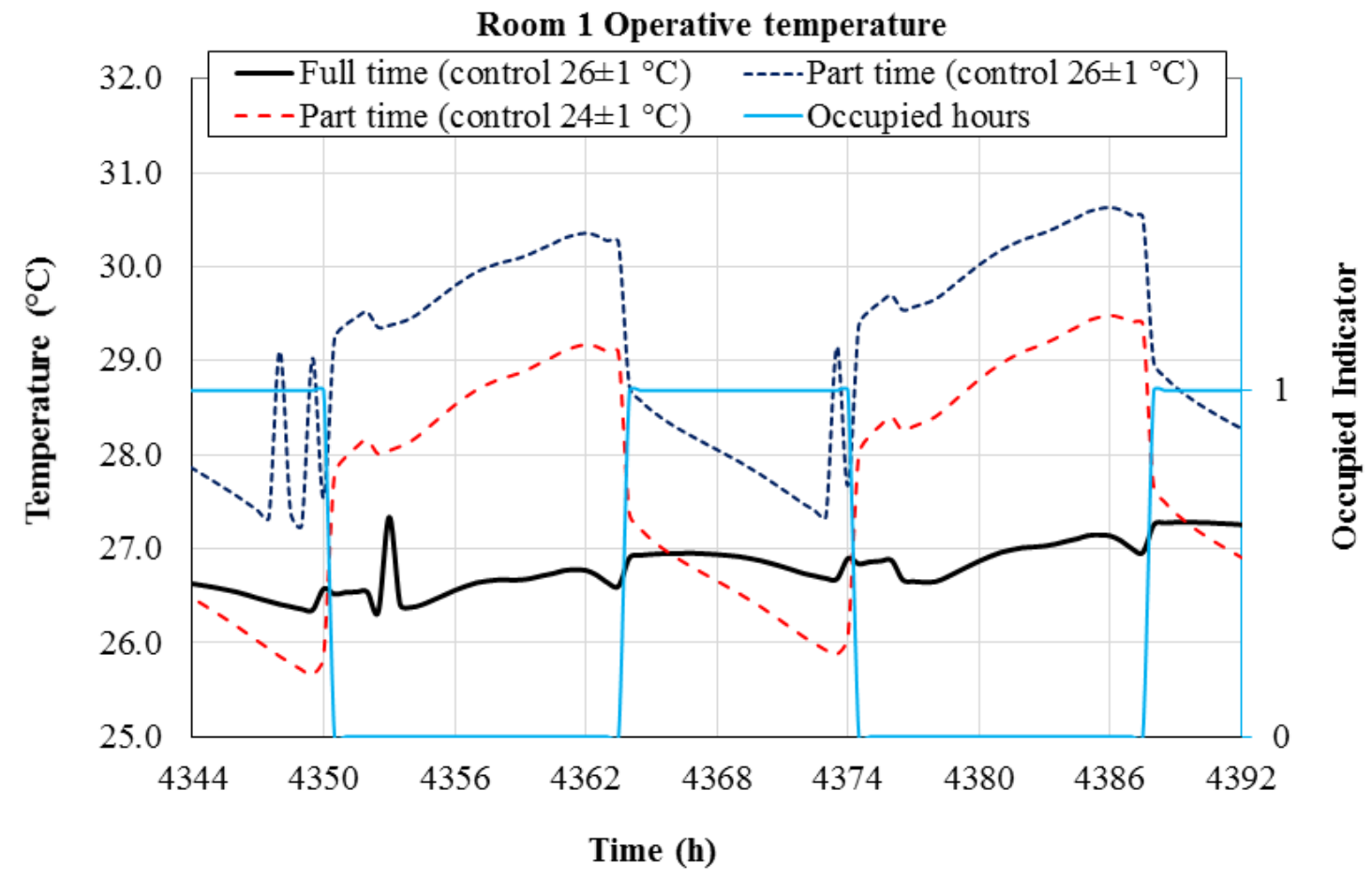

Figure 15 Comparison of operative temperatures of room R1 with heavy weight walls 
on two continuously hot days ( $1^{\text {st }}-2^{\text {th }}$ July) in Changsha climate

\subsection{Impact of different insulation placements on the heavy weight external wall compositions under the same thermal mass}

Although some researchers argued that the internal insulation performs significantly better than the external insulation for external wall compositions in the building energy conservation [26, 27], different insulation placements of the heavy weight wall compositions with the same thermal mass and U-value are compared to confirm the point. As shown in Figures 6 and 7, there is a slight difference of ideal H\&C loads between the cases of external and internal insulations either in the full time or in the part time patterns. Statistical results of the required capacities of the heat and cold supply powers for the three functional rooms of the studied flat in different cities given in Table 4 also suggest that there is just a minor difference between cases with external and internal insulations. Table 7 lists the total building H\&C loads with different insulation placements under fixed room temperature control bands. The differences of sensible $\mathrm{H} \& \mathrm{C}$ loads between the cases with external and internal insulations in both patterns are small. In the full time pattern, there is no obvious advantage for the internal insulation compared to the external insulation, while the internal insulation tends to save a small amount of building $\mathrm{H} \& \mathrm{C}$ loads in the part time pattern. The largest advantage of the internal insulation appears in Chongqing, where it can help to save $\mathrm{H} \& \mathrm{C}$ loads in the part time pattern by $6.3 \%$ and $3.6 \%$, respectively, compared to the cases of external insulation. It suggests that the use of internal insulation on external 
walls is slightly superior to that of external insulation in the part time pattern in terms of building $\mathrm{H} \& \mathrm{C}$ loads. To explain the minor superiority of using internal insulation, Figure 16 gives the calculating node temperatures of the east external wall of Room R1 from outer to inner surface at 18:00 and 20:00 on a typical cold day (20th January) in the part time heating conditions with the temperature control band of $18 \pm 1^{\circ} \mathrm{C}$. At 18:00, when the heating condition begins, the inner wall surface temperature in the case of internal insulation is lower than that in the case of external insulation. Two hours later, at 20:00, the wall inner surface temperatures in both cases of internal and external insulations achieve nearly the same value. It is assumed that the heat absorption by the external walls with internal insulation is negligible in the temperature rise process, as the thermal mass of the internal insulation layer is very small. When it comes to the case of external insulation, there is a portion of heat absorption by the internal side of the external walls due to non-negligible thermal mass of the heavy weight component, although the temperature rise of the wall inner surface is small. The heat absorption by the inner side of the external walls with external insulation is then added to the building heating loads, resulting in a slightly higher heating loads compared to the case of internal insulation. Furthermore, it is noteworthy that in Figure 16 the heat just transfers from the wall inner surface temperature node (twl_inner) to the adjacent calculating temperature node (twl_n8) with a small heat transmittance depth of circa $35 \mathrm{~mm}$ in $2 \mathrm{~h}$. It indicates that the heat storage due to thermal mass impact of external walls in the part time pattern is not intensive. This is why just a minor reduction of heating loads is observed in the case of external insulation compared to that of internal insulation. To 
enlarge the effect of wall heat storage and release in the part time pattern for building energy conservation, some high thermal mass materials (e.g. phase change materials) should be adopted and specific technology should be developed. Besides, it is inferred that previous work $[26,27]$ overestimated the advantage of internal insulation due to a simplified lumped parameter model on the thermal mass layers of the external walls.

Table 7 Total sensible building H\&C loads with different insulation placements under room temperature control bands $\left(18 \pm 1^{\circ} \mathrm{C}\right.$ for heating and $26 \pm 1^{\circ} \mathrm{C}$ for cooling)

\begin{tabular}{|c|c|c|c|c|c|}
\hline \multirow[b]{2}{*}{ Cities } & \multirow[b]{2}{*}{$\begin{array}{l}\text { Insulation } \\
\text { placement }\end{array}$} & \multicolumn{2}{|c|}{ Full time pattern } & \multicolumn{2}{|c|}{ Part time pattern } \\
\hline & & $\begin{array}{l}\text { Sensible } \\
\text { heating } \\
\text { load } \\
\left(\mathrm{kWh} /\left(\mathrm{m}^{2}\right.\right. \\
\text { a) })\end{array}$ & $\begin{array}{l}\text { Sensible } \\
\text { cooling } \\
\text { load } \\
\left(\mathrm{kWh} /\left(\mathrm{m}^{2}\right.\right. \\
\text { a) })\end{array}$ & $\begin{array}{l}\text { Sensible } \\
\text { heating } \\
\text { load } \\
\left(\mathrm{kWh}\left(/ \mathrm{m}^{2}\right.\right. \\
\text { a)) }\end{array}$ & $\begin{array}{l}\text { Sensible } \\
\text { cooling } \\
\text { load } \\
\left(\mathrm{kWh} /\left(\mathrm{m}^{2}\right.\right. \\
\text { a) })\end{array}$ \\
\hline \multirow{4}{*}{ Chongqing } & External & 22.53 & 29.33 & 14.67 & 22.73 \\
\hline & Middle & 22.43 & 29.27 & 14.63 & 22.63 \\
\hline & Internal & 22.36 & 29.14 & 13.74 & 21.92 \\
\hline & $\begin{array}{l}\text { Maximum } \\
\text { deviation }\end{array}$ & $-0.74 \%$ & $-0.65 \%$ & $-6.34 \%$ & $-3.60 \%$ \\
\hline \multirow{4}{*}{ Changsha } & External & 25.12 & 31.07 & 17.09 & 23.40 \\
\hline & Middle & 25.13 & 30.91 & 17.06 & 23.30 \\
\hline & Internal & 25.36 & 30.62 & 16.64 & 22.46 \\
\hline & $\begin{array}{l}\text { Maximum } \\
\text { deviation }\end{array}$ & $0.98 \%$ & $-1.46 \%$ & $-2.63 \%$ & $-4.00 \%$ \\
\hline \multirow{4}{*}{ Shanghai } & External & 16.69 & 29.10 & 11.23 & 20.89 \\
\hline & Middle & 16.74 & 28.87 & 11.30 & 20.56 \\
\hline & Internal & 17.10 & 28.52 & 11.23 & 20.03 \\
\hline & $\begin{array}{l}\text { Maximum } \\
\text { deviation }\end{array}$ & $2.44 \%$ & $-2.01 \%$ & $0.00 \%$ & $-4.12 \%$ \\
\hline
\end{tabular}




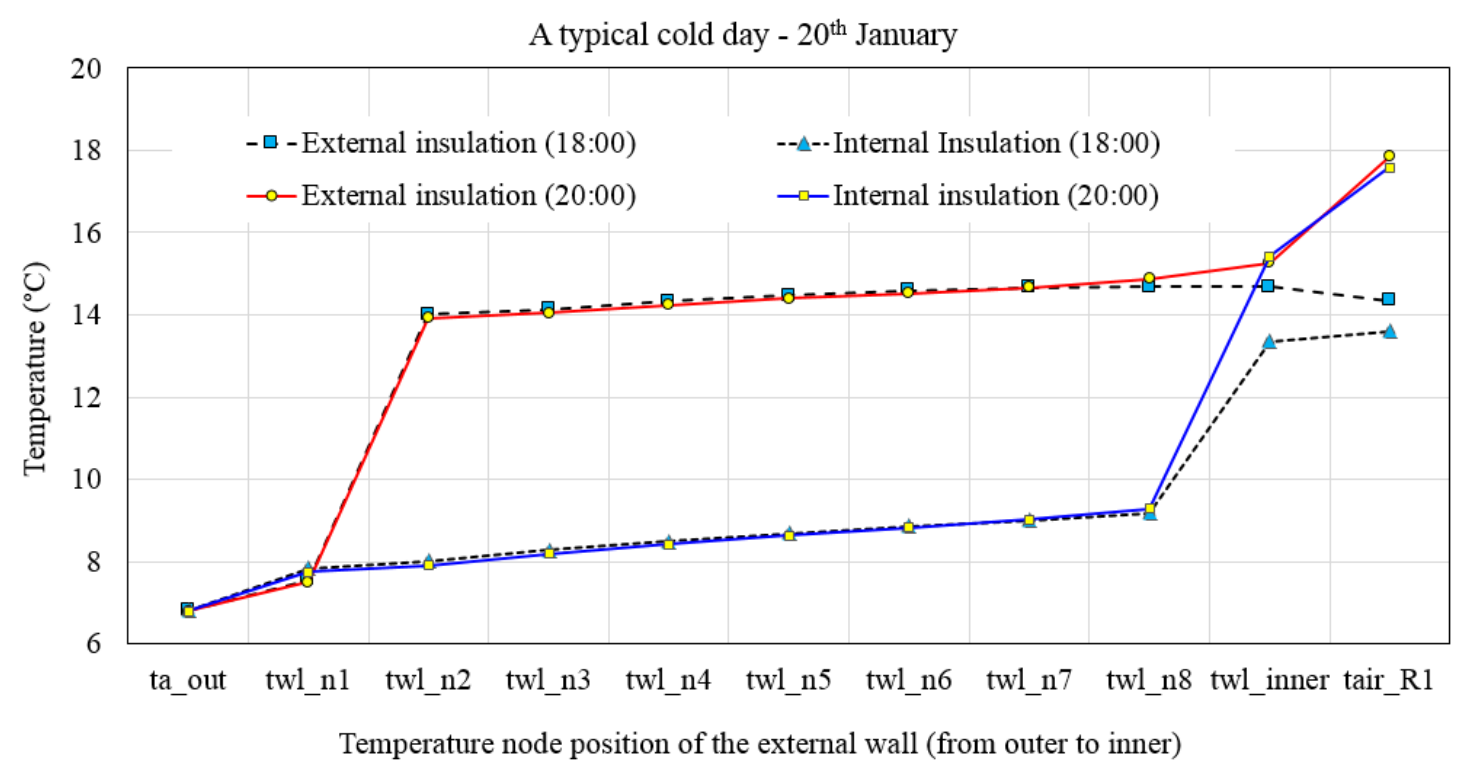

Figure 16 Calculating node temperatures of the east external wall of Room R1 from outer to inner surface on a typical cold day $\left(20^{\text {th }}\right.$ January $)$ in the part time heating conditions with the temperature control band $18 \pm 1{ }^{\circ} \mathrm{C}$ (twl_n $i$ - wall temperature of node ' $i$ '; twl_inner - wall inner surface temperature; tair_R1 - room R1 temperature)

With regard to the room thermal comfort in terms of the operative temperature in the cases of different thermal insulation placements, no consistent advantage is observed either for the internal insulation or for the external insulation, as shown in Figure 17 in the part time pattern. In some occupied hours under the cooling conditions, thermal comfort in the case of internal insulation is worse than that in the case of external insulation, while in some other occupied hours the situation turns inversely, implying the internal insulation will result in a more fluctuated amplitude of the operative temperature compared to the external insulation. As shown in Figure 17, the case of internal insulation on heavy weight external walls is somewhat similar to that of the light weight walls in the cooling conditions. In analogy to the effect of low thermal 
mass discussed in section 4.3 , the internal insulation may result in overheating in summer in the part time patterns. In this sense, the adoption of internal insulation on heavy weight external walls weakens the thermal mass impact of the heavy weight wall composition compared to that of external insulation. It suggests that the high thermal mass in the composition of external walls should be exposed to the indoor air to avoid overheating in the intermittent cooling conditions. In overall consideration of heating and cooling in the HSCW zone, internal insulation is inadvisable as the cooling loads dominate the building thermal energy demands.

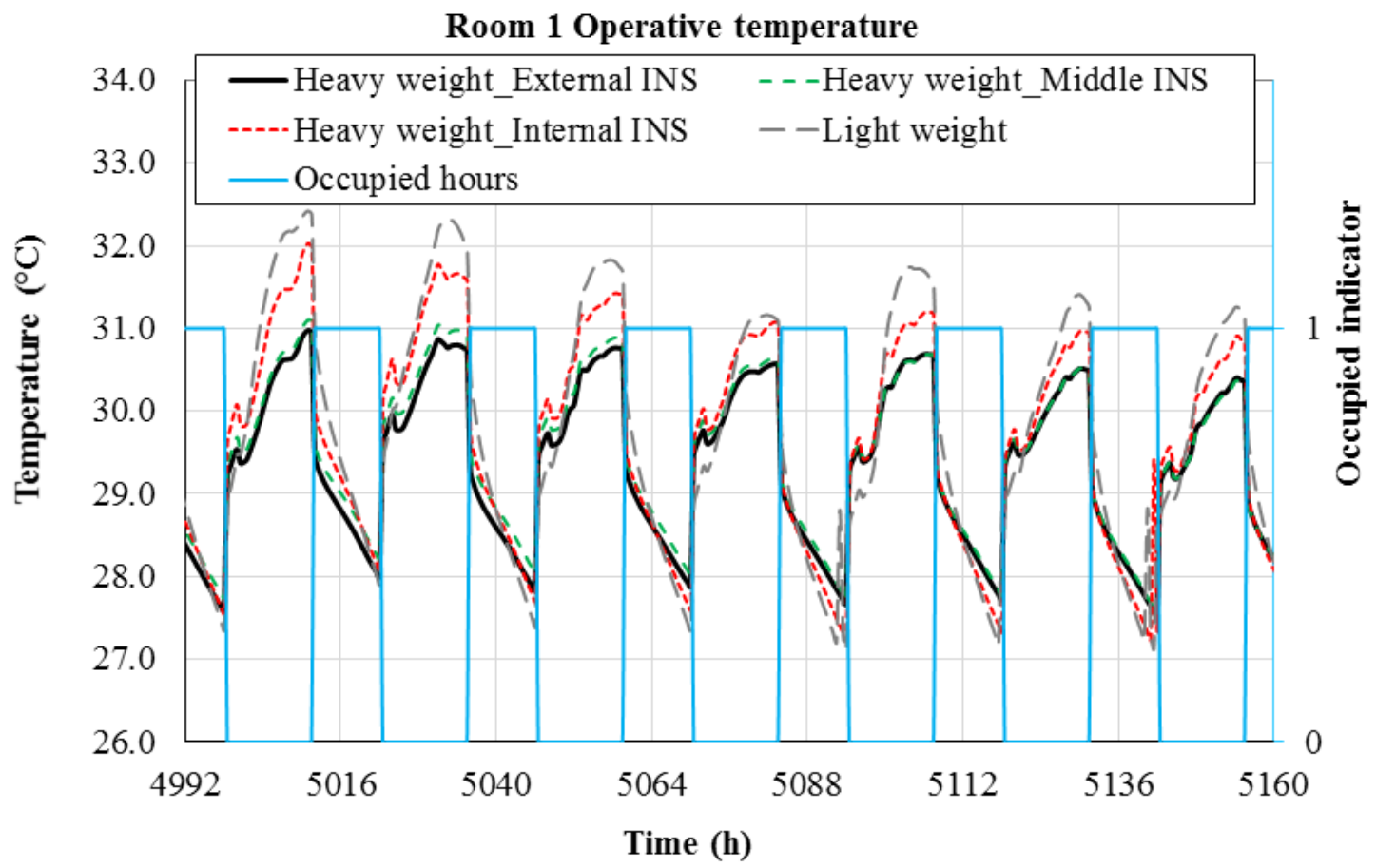

Figure 17 Operative temperature of R1 with different insulation placements of external walls in part time pattern in a week of extreme hot weather (28th July - 3 August; the whole year hour number: $4992 \mathrm{~h}-5160 \mathrm{~h}$ ) in Chongqing climate 


\section{Conclusions}

A high-resolution time interval model of a typical 3-occupant residential apartment has been developed using the state-space method. The model is then validated by the simulation results from EnergyPlus in the same benchmark conditions. Based on the validated model, different thermal mass scenarios under the same $U$-value $\left(0.83 \mathrm{~W} / \mathrm{m}^{2}\right.$ K) are considered to explore the effectiveness of thermal mass of external walls on residential buildings in part-time part-space $\mathrm{H} \& \mathrm{C}$ in the $\mathrm{HSCW}$ zone. It can be concluded that:

(1) Although the ideal H\&C loads of the studied building apartment in the part time pattern in the three cities are reduced by $25.3-31.8 \%$ compared to those in the full time pattern, it is found that the part time $\mathrm{H} \& \mathrm{C}$ loads profiles are much steeper than those of full time patterns. Required capacities of heat/cold supply powers in the part time part space pattern are 1.4-2.1 times as those of corresponding full time part space patterns in three typical cities Chongqing, Changsha, Shanghai.

(2) Simulation deviations of different time intervals in the part time pattern are larger than those in the full time pattern for building $\mathrm{H} \& \mathrm{C}$ loads calculations. For the part time pattern, the conventional time interval of 1 hour overestimates building $\mathrm{H} \& \mathrm{C}$ loads by around $7-8 \%$ compared to the case of $10 \mathrm{~min}$ time interval. It is recommended that $15-30$ min time interval should be adopted for high resolution calculations in the intermittent occupancy.

(3) No significant difference is observed for different thermal mass of external 
walls under the same U-value in the ideal building H\&C loads calculations of residential buildings in the $\mathrm{HSCW}$ climates. However, low thermal mass is proven to influence the thermal comfort control of functional rooms (bedrooms and sitting room) in terms of room operative temperature from the perspective of heating/cooling system control. Using light or medium weight external walls may result in overheating in summer and thus increasing the complexity of room thermal comfort control. To easily control the thermal comfort of a building and save energy, high thermal mass of external walls helps to reduce the complexity of thermal comfort control and required capacities of supply powers.

(4) With regard to different insulation placements of external wall compositions under the same thermal mass, it is observed that the use of internal insulation on external walls is slightly superior to that of external insulation for energy saving in the part time pattern and the previous work overestimated the advantage of internal insulation due to a simplified model on the thermal mass layers. The effect of internal insulation on heavy weight external walls is similar to that of light weight walls and the adoption of internal insulation on heavy weight walls weakens the thermal mass impact of the wall compositions compared to that of external insulation. High thermal mass in the composition of external walls should be exposed to the indoor air to avoid overheating in the intermittent cooling conditions. In an overall consideration of heating and cooling in the HSCW zone, the internal insulation is inadvisable as the cooling loads dominate the building thermal energy demands. 


\section{Conflicts of interest}

The authors certify that they have NO affiliations with or involvement in any organization or entity with any financial interest or non-financial interest in the subject matter or materials discussed in this paper. The authors declare that there is no conflict of interest.

\section{Acknowledgments}

The research work is based on the UK-China collaborative research project 'Low carbon climate-responsive Heating and Cooling of Cities (LoHCool)' supported by the UK Engineering and Physical Sciences Research Council (EPSRC Grant no. EP/N009797/1) and the National Natural Science Foundation of China (NSFC Grant no. 51561135002$)$. The research is associated with the National Key R\&D Program of China 'Solutions to Heating and Cooling of Buildings in the Yangtze River Region' (Grant no: 2016YFC0700300). The authors wish to thank Dr. Vincenzo Costanzo for discussion and Ms Xinyi Li for providing the plain layout of typical 3-occupant apartment.

\section{Appendix A. Supplementary material}

Supplementary material associated with the building residential apartment models developed in Matlab programs are openly available in the University of Reading 
Research Data Archive at: http://dx.doi.org/10.17864/1947.170. It can be accessed online using the unique DOI.

\section{References}

[1] C. Martani, D. Lee, P. Robinson, R. Britter, C. Ratti, ENERNET: Studying the dynamic relationship between building occupancy and energy consumption, Energy and Buildings 47 (2012) 584-591.

[2] A. Roetzel, A. Tsangrassoulis, U. Dietrich, Impact of building design and occupancy on office comfort and energy performance in different climates, Building and Environment 71 (2014) 165-175.

[3] M.S. Gul, S. Patidar, Understanding the energy consumption and occupancy of a multi-purpose academic building, Energy and Buildings 87 (2015) 155-165.

[4] R. Yao, V. Costanzo, X. Li, Q. Zhang, B. Li, The effect of passive measures on thermal comfort and energy conservation. A case study of the hot summer and cold winter climate in the Yangtze River region, Journal of Building Engineering 15 (2018) 298-310.

[5] Z. Wang, Z. Zhao, B. Lin, Y. Zhu, Q. Yang, Residential heating energy consumption modeling through a bottom-up approach for China's Hot Summer-Cold Winter climate region, Energy and Buildings 109 (2015) 65-74.

[6] L. Pan, Q. Xu, Y. Nie, T. Qiu, Analysis of climate adaptive energy-saving technology approaches to residential building envelope in Shanghai, Journal of 
Building Engineering 19 (2018) 266-272.

[7] A. Reilly and O. Kinnane, The impact of thermal mass on building energy consumption, Applied Energy 198 (2017) 108-121.

[8] The U.S. Department of Energy, EnergyPlus, https://energyplus.net/.

[9] S. Ferrari and V. Zanotto, Approximating Dynamic Thermal Behaviour of the Building Envelope, in: Building Energy Performance Assessment in Southern Europe, SpringerBriefs in Applied Sciences and Technology, Springer, Cham (2016) 21-33.

[10] G. Ficco, F. Iannetta, E. Ianniello, F. R. d'Ambrosio Alfano, M. Dell'Isola, Uvalue in situ measurement for energy diagnosis of existing buildings, Energy and Buildings 104 (2015) 108-121.

[11] A. Byrne, G. Byrne, A. Davies, A.J. Robinson, Transient and quasi-steady thermal behaviour of a building envelope due to retrofitted cavity wall and ceiling insulation, Energy and Buildings 61 (2013) 356-365.

[12] R. A. Taylor, M. Miner, A metric for characterizing the effectiveness of thermal mass in building materials, Applied Energy 128 (2014) 156-163.

[13] S. A. Al-Sanea, M. F. Zedan, S. N. Al-Hussain, Effect of thermal mass on performance of insulated building walls and the concept of energy savings potential, Applied Energy 89 (2012) 430-442.

[14] O. Siddiqui, R. Kumar, A. S. Fung, D. Zhang, C. A. Whitman, Modelling for performance prediction of highly insulated buildings with different types of thermal mass, Applied Thermal Engineering 122 (2017) 139-147. 
[15] J. Karlsson, L. Wadsö, M. Öberg, A conceptual model that simulates the influence of thermal inertia in building structures, Energy and Buildings 60 (2013) 146-151.

[16] B. Xu, S. Zhou, W. Hu, An intermittent heating strategy by predicting warm-up time for office buildings in Beijing, Energy and Buildings 155 (2017) 35-42.

[17] F. Leccese, G. Salvadori, F. Asdrubali, P. Gori, Passive thermal behaviour of buildings: Performance of external multi-layered walls and influence of internal walls, Applied Energy 225 (2018) 1078-1089.

[18] S. Gou, V. Nik, J. L. Scartezzini, Q. Zhao, Z. Li, Passive design optimization of newly-built residential buildings in Shanghai for improving indoor thermal comfort while reducing building energy demand, Energy and Buildings 169 (2018) 484506.

[19] Z. Fang, N. Li, B. Li, G. Luo, Y. Huang, The effect of building envelope insulation on cooling energy consumption in summer, Energy and Buildings 77 (2014) 197205.

[20] J. Yu, C. Yang, L. Tian, Low-energy envelope design of residential building in hot summer and cold winter zone in China, Energy and Buildings 40 (8) (2008) 15361546.

[21] X. Liu, Y. Chen, H. Ge, P. Fazio, X. Guo, Determination of optimum insulation thickness for building walls with moisture transfer in hot summer and cold winter zone of China, Energy and Buildings 109 (2015) 361-368.

[22] J. Yu, C. Yang, L. Tian, D. Liao, A study on optimum insulation thicknesses of external walls in hot summer and cold winter zone of China, Applied Energy 86 
(11) (2009) 2520-2529.

[23] F. F. Cyrille Vincelas, T. Ghislain, The determination of the most economical combination between external wall and the optimum insulation material in Cameroonian's buildings, Journal of Building Engineering 9 (2017) 155-163.

[24] L. Aditya, T. M. I. Mahlia, B. Rismanchi, H. M. Ng, H. B. Aditiya, A review on insulation materials for energy conservation in buildings, Renewable and Sustainable Energy Reviews 73 (2017) 1352-1365.

[25] X. Meng, T. Luo, Y. Gao, L. Zhang, X. Huang, C. Hou, Q. Shen, E. Long, Comparative analysis on thermal performance of different wall insulation forms under the air-conditioning intermittent operation in summer, Applied Thermal Engineering 130 (2018): 429-438.

[26] S. A. Al-Sanea, M. F. Zedan, S. N. Al-Hussain, Effect of masonry material and surface absorptivity on critical thermal mass in insulated building walls, Applied Energy 102(2013) 1063-1070.

[27] L. Yuan, Y. Kang, S. Wang, K. Zhong, Effects of thermal insulation characteristics on energy consumption of buildings with intermittently operated air-conditioning systems under real time varying climate conditions, Energy and Buildings 155 (2017) 559-570.

[28] S. Verbeke, A. Audenaert, Thermal inertia in buildings: A review of impacts across climate and building use, Renewable and Sustainable Energy Reviews 82 (2018) $2300-2318$.

[29] BSI, BS EN ISO 7730:2005, Ergonomics of the thermal Environment- Analytical 
Determination and Interpretation of thermal comfort Using Calculation of the PMV and PPD Indices and Local thermal comfort Criteria, British Standards Institution, London, 2005.

[30] CIBSE, CIBSE TM52 The Limits of Thermal Comfort: Avoiding Overheating in European Buildings, The Chartered Institution of Building Services Engineers, London, 2013.

[31] MOHURD, Design Standard for Energy Efficiency of Residential Buildings in Hot Summer and Cold Winter Zone, JGJ 134-2010, 2010 (in Chinese).

[32] Y. Jiang, State-space method for the calculation of air-conditioning loads and the simulation of thermal behaviour of the room, ASHRAE Transaction 88 (1981) $122-132$.

[33] T. Hong, Y. Jiang, A new multizone model for the simulation of building thermal performance, Building Environment 32 (2) (1997) 123-128.

[34] Tsinghua University DeST Development Group, Simulation analysis methods of built environment systems: DeST, China Architecture \& Building Press, 2006.

[35] D. Yan, J. Xia, W. Tang, F. Song, X. Zhang, Y. Jiang, DeST - an integrated building simulation toolkit. Part I: Fundamentals, Building Simulation 2 (2008) $95-110$.

[36] X. Zhang, J. Xia, Z. Jiang, DeST - an integrated building simulation toolkit. Part II: Applications, Building Simulation 3 (2008) 193-209.

[37] J.A. Duffie, W.A. Beckman, Solar Engineering of Thermal Processes, $4^{\text {th }}$ edition, John Wiley \& Sons, New York, 2013. 
[38] GB50176-2016, Code for thermal design of civil building, China Architecture \& Building Press, 2016.

[39] W.C. Swinbank, Long-wave kinematic viscosity from clear skies, Quarterly Journal of the Royal Meteorological Society 90(1964) 488-493.

[40] China Meteorological Bureau, Climate Information Center, Climate Data Office and Tsinghua University, Department of Building Science and Technology. 2005. China Standard Weather Data for Analyzing Building Thermal Conditions, April 2005. Beijing: China Building Industry Publishing House, ISBN 7-112-07273-3 (13228).

[41] The U.S. Department of Energy, EnergyPlus ${ }^{\mathrm{TM}}$ Version 8.8.0 Documentation, Engineering Reference, September 26, 2017.

[42] ASHRAE, ASHRAE Handbook-HVAC Systems and Equipment, American Society of Heating, Refrigerating and Air-conditioning Engineers, Inc., Atlanta, 2012. 


\section{Table Captions:}

Table 1 Building envelope components of the benchmark condition

Table 2 Occupancy schedule

Table 3 Total sensible H\&C loads in full-time and part-time part-space patterns in three cities in the HSCW zone $\left(18{ }^{\circ} \mathrm{C}\right.$ for heating and $26^{\circ} \mathrm{C}$ for cooling)

Table 4 Required capacities of heat or cold supply powers for three functional rooms in the studied flat in three different cities in the HSCW zone

Table 5 Comparison of building $\mathrm{H} \& \mathrm{C}$ loads in different time intervals with room temperature control bands of $18 \pm 1^{\circ} \mathrm{C}$ for heating and $26 \pm 1{ }^{\circ} \mathrm{C}$ for cooling in Changsha climate

Table 6 Three representative thermal mass compositions of external walls $(U=0.83$ $\left.\mathrm{W} /\left(\mathrm{m}^{2} \mathrm{~K}\right)\right)$

Table 7 Total sensible building $\mathrm{H} \& \mathrm{C}$ loads with different insulation placements under room temperature control bands $\left(18 \pm 1{ }^{\circ} \mathrm{C}\right.$ for heating and $26 \pm 1{ }^{\circ} \mathrm{C}$ for cooling)

\section{Figure Captions:}

Figure 1 Research framework of the present study

Figure 2 Plain layout of a typical 3-occupant building apartment

Figure 3 Flow Chart of the Matlab program for calculating ideal building H\&C loads with fixed room target temperatures

Figure 4 Temperature comparison of room R1 between the calculation results of Matlab program and EnergyPlus 
Figure 5 Heating load powers of Room R1 in the part time heating pattern from January to February (the whole year hour number: $0-1416 \mathrm{~h}$ )

Figure 6 Total sensible heating load powers of the building apartment in full time and part time patterns in a typical week of relatively cold weather $\left(2^{\text {nd }}-8^{\text {th }}\right.$ February $)$

(RC-ExtINS denotes reinforced concrete with external insulation for external walls in the benchmark condition; RC-IntINS denotes internal insulation is used for the reinforced concrete walls)

Figure 7 Comparison of sensible $\mathrm{H} \& \mathrm{C}$ loads in full time and part time patterns (a) heating load powers of R1 in a week of relatively cold weather $\left(2^{\text {nd }}-8^{\text {th }}\right.$ February); (b) heating load powers of R5 in a week of relatively cold weather $\left(2^{\text {nd }}-8^{\text {th }}\right.$ February);(c) cooling load powers of R1 in a week of extreme hot weather $\left(1^{\text {st }}-7^{\text {th }} \mathrm{July}\right)$; (d) cooling load powers of R5 in a week of extreme hot weather $\left(1^{\text {st }}-7^{\text {th }} \mathrm{July}\right)$

Figure 8 Total sensible cooling load powers of three thermal mass cases in the full time pattern during cooling period $\left(15^{\text {th }}\right.$ June $-31^{\text {st }}$ August; the whole year hour number: $3960 \mathrm{~h}-5832 \mathrm{~h}$ ) in Changsha climate

Figure 9 Total sensible cooling load powers in full time cooling pattern in Changsha climate (a) in a week of extreme hot weather $\left(1^{\text {st }}-7^{\text {th }}\right.$ July); (b) in a week of nonextreme hot weather $\left(7^{\text {th }}-13^{\text {th }}\right.$ August $)$

Figure 10 (a) AUST (Averaged Uncooled Surface Temperature); (b) Operative temperature of Room R1 under different thermal mass in full time pattern during the cooling period $\left(15^{\text {th }}\right.$ June $-31^{\text {st }}$ August; the whole year hour number: $3960 \mathrm{~h}-5832 \mathrm{~h}$ ) in Changsha climate

Figure 11 Operative temperature of Room R1 under different thermal mass in a week of extreme hot weather $\left(1^{\text {st }}-7^{\text {th }}\right.$ July; the whole year hour number: $\left.4344 \mathrm{~h}-4512 \mathrm{~h}\right)$ in Changsha climate

Figure 12 Operative temperature of room R1 with a cooling temperature control band 
$\left(26 \pm 1^{\circ} \mathrm{C}\right)$ under different thermal mass in a week of extreme hot weather $\left(1^{\text {st }}-7^{\text {th }} \mathrm{July}\right.$; the whole year hour number: $4344 \mathrm{~h}-4512 \mathrm{~h}$ ) in Changsha climate

Figure 13 Operative temperature of room R1 with a heating temperature control band $\left(18 \pm 1^{\circ} \mathrm{C}\right)$ under different thermal mass in four days of relatively cold weather $\left(2^{\text {nd }}-8^{\text {th }}\right.$ February; the whole year hour number: $816 \mathrm{~h}-912 \mathrm{~h}$ ) in Changsha climate

Figure 14 Operative temperature of room R1 with a cooling temperature control band $\left(26 \pm 1^{\circ} \mathrm{C}\right)$ under different thermal mass in the part time pattern on two continuously hot days ( $1^{\text {st }}-2^{\text {th }}$ July) in Changsha climate

Figure 15 Comparison of operative temperatures of room R1 with heavy weight walls on two continuously hot days $\left(1^{\text {st }}-2^{\text {th }}\right.$ July) in Changsha climate

Figure 16 Calculating node temperatures of the east external wall of Room R1 from outer to inner surface on a typical cold day (20th January) in the part time heating conditions with the temperature control band $18 \pm 1{ }^{\circ} \mathrm{C}$ (twl_n $i$ - wall temperature of node ' $i$ '; twl_inner - wall inner surface temperature; tair_R1 - room R1 temperature) Figure 17 Operative temperature of R1 with different insulation placements of external walls in part time pattern in a week of extreme hot weather (28th July - 3 August; the whole year hour number: $4992 \mathrm{~h}-5160 \mathrm{~h}$ ) in Chongqing climate 